\title{
COMPETITION IN BUSINESS TAXES AND PUBLIC SERVICES: ARE PRODUCTION-BASED TAXES SUPERIOR TO CAPITAL TAXES?
}

\author{
Elisabeth Gugl and George R. Zodrow
}

\begin{abstract}
Although most of the tax competition literature focuses on the provision of local public services to households, several papers analyze tax competition when capital taxes are used to finance local public services provided to businesses, examining the conditions under which such services are provided efficiently, under-provided, or over-provided. In addition, several prominent observers have noted that "benefit-related" business taxation is desirable on both efficiency and equity grounds and argued that such taxation should take the form of a tax based on production, such as an origin-based value-added tax. We evaluate this contention in this paper, comparing the relative efficiency properties of these alternative business taxes. Our simulation results suggest that under many, but not all, circumstances it is more efficient to finance business public services with an origin-based production tax rather than a source-based capital tax.
\end{abstract}

Keywords: business public services, infrastructure, tax competition, capital taxes, production taxes, origin-based VAT

JEL codes: $\quad H 41, H 42, H 21, H 11$

Revised version published in the National Tax Journal, September, 2015, Volume 68, Issue 3S, pp. 767-802

Elisabeth Gugl: Department of Economics, University of Victoria, Victoria, British Columbia, Canada (egugl@uvic.ca)

George R. Zodrow: Department of Economics and Baker Institute for Public Policy, Rice University, Houston TX, USA; Centre for Business Taxation, Oxford, UK (zodrow@ rice.edu) 


\section{INTRODUCTION}

Most of the literature on interjurisdictional tax competition focuses on the provision of local public services to households financed with taxes on mobile capital; for reviews of this voluminous literature, see Wilson (1999), Zodrow (2003), Wildasin and Wilson (2004), and Devereux and Loretz (2013). However, a number of papers, dating back to Zodrow and Mieszkowski (1986), analyze tax competition when capital taxes (or a combination of capital taxes and head taxes) are used to finance local public services provided to businesses, examining whether such services are provided efficiently, under-provided, or over-provided. In addition, several prominent experts on state and local finance have noted that "benefit-related" business taxation is desirable on both efficiency and equity grounds, and have argued that such taxation is more closely approximated by a tax on production, such as an origin-based value-added tax (VAT), rather than a tax on capital or capital income.

In this paper, we evaluate this contention, comparing within the context of a standard model of interjurisdictional tax competition the relative efficiency properties of business taxes that are assessed on production to those assessed on capital. The key issue is which of the two taxes more closely approximates a user charge for public services and/or taxes a relatively less mobile tax base. For example, taxing the fixed input, labor, leads to efficiency in the original Zodrow-Mieszkowski model, as does taxing capital in models (discussed below) in which business public services are perfect complements, so that taxing capital is equivalent to imposing user charges for business public services. More generally, however, if there is substitution between capital and business public services, the relative mobility of the tax bases under the capital tax and the production tax is critical to determining the relative efficiency of the two taxes. The production tax is assessed on a less mobile tax base and also to some extent includes in its base the public service (since a production tax is equivalent to a tax on all inputs at the 
same tax rate). Hence, one might expect that a production tax will be more efficient than a capital tax as it taxes a less mobile tax base and more closely resembles a benefit tax. We show in this paper that this intuition indeed holds in many cases — but that under certain circumstances, described below, the capital tax can be more efficient than the production tax.

Three strands of the literature on state and local taxation of businesses are particularly relevant for our analysis. The first is the extension of the classic Tiebout (1956) model, under which interjurisdictional competition with perfectly mobile consumers and head tax finance results in an efficient level of local public services to households, to the efficient provision of business public services. This literature is best exemplified by Oates and Schwab (1991), who construct a multi-jurisdictional tax competition model in which firms in each jurisdiction produce output using capital, labor, and a publicly provided input financed with a property tax on capital. The key assumption of the Oates-Schwab model is that the amount of the publicly provided input - which, following most of the literature, is modeled as a publicly-provided private good - is allocated to firms precisely in proportion to the stock of capital that they utilize in that jurisdiction. ${ }^{1}$ This assumption is sufficient to make a property tax on capital equivalent to a user charge for services provided, so that local business public services are provided efficiently. A broadly similar approach is utilized by Sinn (1997), who assumes that each unit of capital must use a public service once before it can be utilized in production (e.g., capital must make a single trip on a congestible public highway before being placed in service), again implying that an appropriately set property tax on capital functions as a user

\footnotetext{
1 Oates and Schwab also assume that a local public good is provided to residents of the jurisdiction and financed with head taxes, following the approach utilized in the basic Tiebout model.
} 
charge/congestion fee for the public service and ensures efficiency in the allocation of resources to business public services.

A second closely related strand of this literature considers instead the case in which the taxes used to finance business public services do not result in an efficient equilibrium.

Specifically, this literature relaxes the rather stringent assumption that the ratio of capital and public services is fixed in production, and instead assumes more generally that the production function simply includes public services as an input that is financed with property taxes (or any source-based tax on capital). For example, although Zodrow and Mieszkowski (ZM) (1986) focus on public services provided to residents, they also consider the case of publicly-provided business public services financed with property taxes, obtaining two main results. First, starting from an initial equilibrium in which the efficient level of business public services is financed entirely with head taxes, they find that — as in the case of public services provided to households - the use of the property tax to finance local business public services leads to underprovision of such services, as local governments reduce reliance on the property tax to avoid driving mobile capital out of their jurisdictions. However, once property tax finance is introduced, the effect of a tax increase on the level of business public services is theoretically ambiguous, as it depends on how the perceived tax responsiveness of mobile capital, which interacts with the initial tax rate when it is positive in the initial equilibrium, varies as the tax rate increases.

$\mathrm{ZM}$ make two assumptions in their analysis that guarantee that an increase in the property tax rate in a jurisdiction always results in capital outflow from the taxing jurisdiction. Several subsequent papers have investigated the implications of alternative assumptions, on the grounds that the business public services financed with a property tax increase might increase the 
productivity of capital sufficiently that capital would be attracted to the jurisdiction. ${ }^{2}$ For example, Bayinder-Upman (1998) constructs a model in which property tax rate competition leads to underprovision (overprovision) of business public services as long as an increase in the tax rate causes capital outflows (inflows). Similarly, Dhillon, Wooders, and Zissimos (2007) construct a tax competition model in which a sufficient degree of complementarity between capital and the public good implies that a tax increase results in capital inflows and show that underprovision, overprovision, and efficient provision can result, depending on the nature of this complementarity. ${ }^{3}$

The third strand of the literature on state and local taxation of businesses relevant to our analysis reflects a very different approach. Rather than examining the effects of property tax finance on local public service provision, several prominent observers have argued that state and local taxation of businesses to finance the provision of business public services should be based on production rather than the amount of capital utilized. This argument assumes that the benefits of business public services are closely related to production levels and then draws on the conventional wisdom that both efficiency and equity considerations imply that state and local governments should finance public services, including those provided to businesses, with user charges and fees that function as benefit taxes. The logic underlying this argument is straightforward. On efficiency grounds, benefit taxes are desirable because they ensure that businesses pay the full social costs of all inputs into the production process; by comparison, if public inputs are provided at zero marginal cost, businesses will face an incentive to expand

\footnotetext{
${ }^{2}$ We discuss this literature in more detail in Section IV.

3 See also Noiset (1995) and Matsumoto (1998), who obtains similar results in a model in which business public services are a pure public good, and Matsumoto (2000b), who examines the implications of alternative assumptions regarding the congestibility of business public services.
} 
beyond efficient levels of production. (Note that if businesses pay other non-benefit-related taxes, as is typically the case, this tendency toward over-expansion acts to offset to some extent the incentives for under-production due to these other taxes). On equity grounds, benefit taxes are desirable because they are consistent with the benefit principle, which states that the beneficiaries of public services should pay taxes sufficient to cover their cost.

However, if user charges are not available or are infeasible for technical, political, or other reasons, state and local governments must use alternative tax instruments to finance public services. In this regard, numerous observers have argued that subnational governments, because they are effectively small open economies, should avoid inefficient source-based taxes on highly mobile capital that are not directly related to the benefits of business public services (Gordon, 1986; Razin and Sadka, 1991; Zodrow and Mieszkowski, 1983). Nevertheless, in the United States, state and local taxes often take the form of property taxes, corporate income taxes, or retail sales taxes that are inappropriately assessed on business capital — all of which correspond roughly to taxes on capital that tend to drive mobile capital out of the taxing jurisdiction and also distort a wide variety of decisions, including those regarding capital accumulation and allocation and the level of public services provided, as stressed in the tax competition literature. Moreover, the extent of such taxation of business inputs is significant in the United States. For example, using 2013 data provided by Phillips et al. (2013), businesses paid $\$ 442.2$ billion in state and local property taxes, sales taxes on business inputs, and corporate income taxes, which amounts to roughly 30 percent of total state and local taxes. ${ }^{4}$

4 Phillips et al. (2013) also estimate that total business taxes paid, including property taxes, sales and excise taxes paid by businesses on their input purchases and capital expenditures, gross receipts taxes, corporate income and franchise taxes, business and corporate license taxes, unemployment insurance taxes, individual income taxes paid by owners of non-corporate (pass- through) businesses, and other state and local taxes that are the statutory liability of business taxpayers, amount to $\$ 671$ billion or 45 percent of total state and local taxes paid. 
For these reasons, Bird (2002) argues that the benefit principle of taxation supports the use of a production tax — that is, to the extent that public services are provided to business, firms should be taxed to pay for the benefits they receive. More specifically, he argues that an origin-based, consumption-based $\mathrm{VAT}^{5}$ would tax business more broadly and in a way more closely related to benefits received than would a tax on capital (such as a property tax at the municipal level, or a state or provincial level corporate tax, or a sales tax that taxes firms' capital inputs), and would thus be more consistent with the concept of a benefit tax. In addition, McLure (2003) argues that the increasing importance of electronic commerce makes the traditional destination-based VAT difficult to enforce, and thus provides a complementary argument for the use of an origin-based VAT.

This paper extends this literature in two ways, drawing on a model constructed in Gugl and Zodrow (2014), which to our knowledge is the first formal analysis of the arguments supporting production-based business taxes over capital taxes. First, we present the results of some simulation analyses that examine within the context of this model the efficiency properties of business taxes that are assessed on production levels relative to those that are assessed on capital. In particular, we show how the level of business public service provision in our model depends on the $\log$ (sub/super) modularity of the production function. Second, we provide a brief review of the literature on capital tax competition when public services are provided to businesses, attempting to reconcile various results regarding the effects of capital taxation on the extent to which business public services are under-provided, over-provided, or provided efficiently.

5 Note that an income-based VAT could also be viewed as a production-related tax, as could a sales or gross receipts tax that included deductions for input costs (other than labor) and thus approximated a VAT. 
The paper is organized as follows. In the following section, we outline the model and our comparison of the efficiency properties of production and capital taxes. Section III provides simulation analyses of the model, focusing on the extent to which business public services are under-provided, over-provided, or provided efficiently. A brief reconciliation of these results with others that have appeared in the literature is presented in Section IV, and the final section summarizes the results and concludes with a discussion of possible policy implications.

\section{OVERVIEW OF THE MODEL AND RESULTS}

\section{A. Key Assumptions in the Model}

The model we construct in Gugl and Zodrow (2014) is broadly similar to the model of symmetric multi-jurisdictional capital tax competition utilized by ZM. There are $N$ identical jurisdictions, each of which faces a local labor market and national markets for capital and a single consumption good. Each jurisdiction perceives itself as a small open economy, and thus takes the rate of return $r$ and the price of the consumption good, which is the numeraire, as given in setting its policies. Residents of a jurisdiction derive utility solely from the consumption of a private good (as only business public services are considered in the model) and labor supply $L$ is assumed to be fixed in each jurisdiction. Each resident owns the same amount of the fixed national capital stock $\bar{K}$ so the residents of a jurisdiction earn capital income $r \bar{K} / N$, where the amount of capital employed in the jurisdiction (denoted by $K$ ) can differ from the amount of capital owned by its residents, $\bar{K} / N$. Each jurisdiction seeks to maximize the income of its residents (and therefore total local consumption).

Given this fairly standard basic structure, a critical issue in the construction of the tax competition model is how the consumption good is produced, especially the role that business public services provided by local governments play in the production of the good; that is, the way that the public service enters as an input into the private production function must be 
specified. This involves two related issues: (1) whether the public service is a publicly provided private input, a congestible public input, or a pure public input; and (2) whether the production function is characterized by constant, increasing, or decreasing returns to scale in the private and public inputs.

We follow Oates and Schwab (1991) and most of the state and local public finance literature in the Tiebout (1956) tradition — as discussed, for example, by Hamilton (1983) — in assuming that the public input is a publicly provided private good (that is, it is subject to congestion to the full extent of a private good), and that the production technology exhibits constant returns to scale (CRS) in all factors, both public and private. While this characterization may not be appropriate for all types of public investments, Gramlich (1993) suggests that many public investment projects fall into this category. Such a technology implies that either privatization of the supply of the public input or charging firms the appropriate user fees would be efficient.

Firms are thus assumed to produce a single consumption good using capital $K$, business public services $B$, and fixed labor $L$, with a production function $F(K, B, L)$ that is CRS in all inputs and strictly concave in $(K, B)$. In addition, we assume complementarity between capital and the public service (but not fixed proportions); that is, the production function is characterized by a strictly positive cross-derivative between capital and the public service $\left(F_{K B}=F_{B K}>0\right)$.

This approach also generally follows most of the literature, including Zodrow and Mieszkowski (1986), Bayindir-Upmann (1998), Keen and Marchand (1997), and Dhillon, Wooders, and Zissimos (2007), and is one of the options considered by Feehan and Matsumoto (2000), and Matsumoto (1998, 2000a, b).

Alternative assumptions are of course possible, and various options are discussed by Feehan and Matsumoto (2000), Richter (1994), Sinn (2003), and Matsumoto (1998, 2000a). In 
addition, as emphasized by Matsumoto (2000a), these two questions are critical to determining the optimal number of firms in a jurisdiction. For example, models such as ours that assume only one firm per jurisdiction implicitly avoid the former question, but have the flavor of a model that assumes the public service provided to businesses is either a pure public good or a pure private good. Matsumoto (2000a) notes that the optimal number of firms in a jurisdiction is one with a publicly provided congestible good if the production technology is CRS in the private inputs only. In contrast, our assumption that the production technology is CRS in all factors including the public input has the advantage that the efficient provision of the public service does not depend on the number of firms, which is indeterminate in the model.

We also must specify how the public service is produced, that is, whether the production of the public service exhibits constant, increasing, or decreasing returns to scale. We follow most of the literature in assuming constant returns to scale and thus constant marginal costs (Oates and Schwab, 1988, 1991; Sinn, 2003; Bayindir-Upmann, 1998; Keen and Marchand, 1997; Richter, 1994; Matsumoto 2000a). Two alternative approaches, which Matsomoto (2000a) points out are equivalent, are to assume either an imperfectly congestible public input and a constant marginal cost of producing that public input, or a perfectly congestible public input (i.e., our publicly provided private service) and decreasing marginal costs of producing the public service.

Given our characterization of the production function, we explore the provision of business public services under local production and capital taxes in the presence of interjurisdictional tax competition. ${ }^{6}$ In particular, we examine the relationship between $\log$ (sub/super) modularity of the production function and the efficiency of local provision of

6 We do not, however, consider other alternative tax instruments; for example, a tax on immobile labor would be preferable to either production or capital taxes in this model, and Bucovetsky and Wilson (1991) show that taxes on labor are generally preferred to taxes on highly mobile capital in models of tax competition even when labor is supplied elastically. 
business public services under these alternative tax structures. The appendix provides a complete discussion of the $\log$ (sub/super) modularity properties of production functions; a summary of those properties is as follows.

Log (sub/super) modularity of a production function in capital and business public services specifies how the marginal productivity of capital is affected by changes in the level of public services and how the marginal productivity of public services is affected by changes in the level of capital. For log (sub/super) modularity these relationships must be symmetric; thus we focus in the following discussion on the impact of public services on the marginal productivity of capital. Specifically, if the production function is log submodular (log modular, log supermodular) in capital and public services, the marginal productivity of capital relative to output decreases (remains constant, increases) as more public services are provided. This occurs if the capital elasticity of production decreases (remains constant, increases) as $B$ increases. More formally, a production function is log modular if and only if the elasticity of the marginal productivity of capital with respect to public services, ${ }_{K B}=F_{K B}\left(B / F_{K}\right)$, is equal to the elasticity of output with respect to public services, ${ }_{B}=F_{B}(K / B)$; it is log submodular if and only if ${ }_{K B}<{ }_{B}$, and log supermodular if and only if ${ }_{K B}>{ }_{B}$.

Log (sub/super) modularity plays an important role in the matching literature when there are search frictions, as positive (negative) assortative matching requires that all matching sets be convex, which is determined by the log modularity properties of the production function (Peters and Siow, 2002; Smith, 2006). However, to the best of our knowledge, the implications of the $\log$ modularity properties of the production function have not been examined in models of interjurisdictional tax competition. We show in the following section that log (sub/super) modularity of the production function determines whether jurisdictions anticipate that an 
increase in business public services financed with a production tax will leave unchanged, increase, or decrease the demand for capital within the taxing jurisdiction and thus lead to efficient provision, overprovision, or underprovision of business public services. In addition, we show that in a capital tax equilibrium underprovision of business public services is guaranteed if the production function is log modular or log submodular, while all of the possible outcomes of efficient provision, overprovision, or underprovision of business services can result under capital tax finance of business public services when the production function is log supermodular. This analysis includes an examination of the implications of the $\log$ modularity properties of the commonly used Cobb-Douglas and constant elasticity of substitution (CES) production functions.

\section{B. Modeling a Production Tax}

The model and results of Gugl and Zodrow (2014), who analyze the efficiency properties of a production tax when public inputs are provided to firms and local jurisdictions compete for mobile capital, can be summarized as follows. ${ }^{7}$ We assume that firms are locally owned and that residents hold a fixed amount of the national capital stock denoted by $\bar{K}$ which is not necessarily invested in their jurisdiction. In the case of user charges, the local jurisdiction charges the constant marginal cost of $\$ 1$ per unit of the public service. If firms are charged user fees for the public service, they pay for all their inputs and employ inputs at a quantity where the value of the marginal productivity of an input equals its marginal cost. Given that jurisdictions are identical $(K=\bar{K})$, this implies that the efficient quantity of the public service in each

7 There is a large literature on the performance on origin-based versus destination-based VATs, and the DiamondMirrlees result assumes the existence of an efficient set of destination-based commodity taxes. However, in all of these models, tax revenues are used to provide public services to residents or to finance an exogenous level of government expenditures rather than providing business public services; see Gugl and Zodrow (2014) for further discussion. 
jurisdiction is the amount for which $F_{B}(\bar{K}, B, L)=1$. Since profits are equal to $=F(\bar{K}, B, L) \quad w L \quad r \bar{K} \quad B$ when user fees are charged, we can rewrite profits as
$=F(\bar{K}, B, L) \quad F_{L} L \quad F_{K} \bar{K} \quad F_{B} B$, which equal zero with constant returns to scale.

However, if the public service is financed with a tax on production or on capital, local firms do not pay directly for the public service and accrue profits. In the case of a tax on production, the local jurisdiction chooses its production tax rate $t$ to maximize total resident income

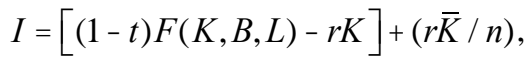

where the first term is the sum of the profits and wage income of residents and the second term is the fixed capital income of local residents. The government chooses it production tax rate to maximize (1) subject to its budget constraint

$$
B=t F(K, B, L) .
$$

Firms pay labor the value of its marginal product and choose capital to maximize profits

or

$$
\max _{K}(1 \quad t) F(K, B, L) \quad r K \quad w L,
$$

which yields the first order condition

$$
r=(1 \quad t) F_{K}(K, B, L) .
$$

Local jurisdictions realize that by increasing their production tax unilaterally, the amount of capital employed in the jurisdiction may change. The right hand side of (4) is the value of the marginal productivity of capital $(V M P K)$ to the firm. This value changes directly with a change in the tax rate at the current level of capital,

$$
\frac{V M P K}{t}=F_{K}+\left(\begin{array}{ll}
1 & t
\end{array}\right) F_{K B} \frac{B}{t},
$$


by reducing the after-tax price of output resulting in a decrease in the VMPK (the first term), and because a change in the tax rate at the current level of capital increases the level of public service (the second term). However, VMPK also changes because the level of capital might change as a result of a change in the production tax. The change of $V M P K$ as $K$ changes is given by

$$
\frac{\partial V M P K}{\partial K}=\left(\begin{array}{ll}
1 & t
\end{array}\right)\left(F_{K K}+F_{K B} \frac{\partial B}{\partial K}\right)
$$

The expressions for $B / t$ and $B / K$ are derived by implicitly differentiating the local jurisdiction's budget constraint (0) with respect to $B$ and $t$ which yields

$$
\frac{B}{t}=\frac{F}{1 t F_{B}}
$$

and by implicitly differentiating (0) with respect to $B$ and $K$ which yields

$$
\frac{B}{K}=\frac{t F_{K}}{1 t F_{B}} .
$$

The local jurisdiction perceives itself as too small to influence the price of capital in the whole economy. Hence it assumes that setting $t$ will not impact $r$. This implies that from the local government's perspective

$$
\frac{\partial V M P K}{\partial t}+\frac{\partial V M P K}{\partial K} \frac{d K}{d t}=F_{K}+\left(\begin{array}{ll}
1 & t
\end{array}\right) F_{K B} \frac{\partial B}{\partial t}+\left(\begin{array}{ll}
1 & t
\end{array}\right)\left(F_{K K}+F_{K B} \frac{\partial B}{\partial K}\right) \frac{d K}{d t}=0 .
$$

Substituting (7) and (8) into (9), and rearranging, we find the perceived change in the jurisdiction's capital in response to an increase in the production tax is

$$
\frac{d K}{d t}=\frac{F_{K}+\left(\begin{array}{ll}
1 & t
\end{array}\right) F_{K B} \frac{F}{1 t F_{B}}}{\left(\begin{array}{ll}
1 & t
\end{array}\right)\left(F_{K K}+F_{K B} \frac{t F_{K}}{1 t F_{B}}\right)} .
$$

The sign of the numerator of $d K / d t$ depends on the relative magnitudes of two opposing 
effects. The first term in $d K / d t$ expresses the marginal decrease in the value of capital to firms due to an increase in $t$. An increase in the production tax at the current level of the capital stock in the jurisdiction lowers the value of the marginal productivity of capital, all else equal. As firms are paid less for their product, this means they would lower the amount of capital to maximize profits and capital would leave the taxing jurisdiction — the "base erosion" effect of the tax increase. However, as shown in the second term, an increase in the production tax at current levels of capital also increases the public service and with it the marginal productivity of capital — the "capital productivity" effect of the tax increase and the associated expansion of business public services - which increases the demand for capital and thus attracts capital to the taxing jurisdiction. The relative magnitudes of the base erosion and capital productivity effects determine whether the local government anticipates an outflow or inflow of capital as it raises its production tax.

Putting both terms in the numerator of $d K / d t$ under the same denominator yields the expression $\left[\left(\begin{array}{ll}1 & t F_{B}\end{array}\right) F_{K}+\left(\begin{array}{ll}1 & t\end{array}\right) F_{K B} F\right] /\left(\begin{array}{ll}1 & t F_{B}\end{array}\right)$. Similarly, the denominator of $d K / d t$ can be written as $(1 \quad t)\left[\left(\begin{array}{ll}1 & t F_{B}\end{array}\right) F_{K K} \quad t F_{K B} F_{K}\right] /\left(\begin{array}{ll}1 & t F_{B}\end{array}\right)$, so the $\left(1 \quad t F_{B}\right)$ term cancels. Gugl and Zodrow (2014) show that the denominator of this new expression of $d K / d t$ is positive.

Rearranging the terms in the numerator of $d K / d t$, the sign of the numerator is determined by the sign of $\left[F_{K}+F_{K B} F\right]+\left[\begin{array}{ll}t\left(F_{K} F_{B}\right. & \left.F_{K B} F\right)\end{array}\right]$.

We next provide the intuition behind why the log (sub/super) modularity properties of the production function play a crucial role in determining efficiency or inefficiency of the production tax. Recall that the production function is log modular if the elasticity of the marginal productivity of capital with respect to the public service is equal to the output elasticity with respect to the public service, so log modularity implies that ${ }_{K B}=F_{K B}\left(B / F_{K}\right)=F_{B}(B / F)={ }_{B}$. 
Hence if the production function is $\log$ modular, $F_{K} F_{B}+F_{K B} F=0$. In setting its production tax, suppose the government chooses one where $F_{B}=1$, given the current level of capital. Then the first term in brackets above can be rewritten as $F_{K} F_{B}+F_{K B} F$. Since the production function is log modular this term necessarily is zero, as is the second term. Hence the numerator of $d K / d t$ in (0) is zero and the government would anticipate no change in the amount of capital employed in its jurisdiction if it set a production tax such that the public service is provided efficiently; that is, in the case of a log modular production function, the base erosion effect is exactly offset by the capital productivity effect. By comparison, in the case of $\log$ supermodularity or $\log$ submodularity of the production function, $F_{K} F_{B}+F_{K B} F \quad 0$, so that the local government anticipates a change in the amount of capital employed if it set its production tax so that $F_{B}=1$ at any given level of capital. In this case, perceiving a change in the amount of capital and setting a production tax that leads to $F_{B}=1$ at current levels of capital is inconsistent. This implies there will be inefficiency - either underprovision or overprovision of public services - when the public good is financed with a production tax and the production function is not log modular. ${ }^{8}$

Note that since all jurisdictions are identical, they will all follow the same tax policy, which implies that capital does not change in any jurisdiction in the symmetric equilibrium; however, each jurisdiction fails to realize this and perceives that a tax increase will cause the capital response shown above.

Gugl and Zodrow derive the optimality condition for the production tax by assuming the government chooses the rate $t$ to

\footnotetext{
${ }^{8}$ We thank Timothy Goodspeed whose comments facilitated this interpretation of the results under the production tax.
} 


$$
\max _{t}(1 \quad t) F(K(t), B(t, K(t)), L) \quad r K(t)+r \bar{K},
$$

subject to (0), (0), and (0). The resulting first order condition is 9

$$
F_{K} t\left(F_{K B} F \quad F_{B} F_{K}\right) \quad F_{K K} F\left(\begin{array}{ll}
F_{B} & 1
\end{array}\right)=0
$$

In the $\log$ modular case, $F_{B}=1$ and $F_{K} F_{B}=F_{K}=F_{K B} F$, which implies that business public services are provided efficiently, and $d K / d t=0$, that is, in this efficient equilibrium each subnational government perceives that the capital stock in its jurisdiction will remain unchanged in response to an increase in the production tax and in equilibrium.

By comparison, if the production function is log submodular or log supermodular, ${ }_{B}$, the level of public services is inefficient, and the optimal production tax rate is

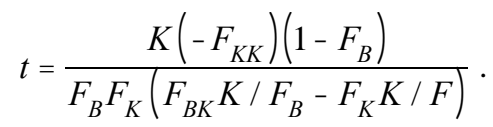

This implies underprovision $\left(F_{B}>1\right)$ if the production function is log submodular and $\left({ }_{K B}<{ }_{B}\right)$, and overprovision $\left(F_{B}<1\right)$ if the production function is log supermodular $\left({ }_{K B}>{ }_{B}\right)$.

\section{Modeling a Capital Tax}

Consider next the case in which local jurisdictions tax capital in order to finance the public services provided to firms. Each jurisdiction chooses its capital tax rate $\tau$ to maximize the aggregate income of its residents, $I=F(K, B, L) \quad(r+\quad) K+r \bar{K}$, subject to the budget constraint $B=K$. In addition, firms choose their capital stock to maximize firm profits, $F(K, B, L) \quad(r+) K \quad w L$, which implies $F_{K}(K, B, L)=(r+\quad)$. Local jurisdictions again

\footnotetext{
${ }^{9}$ See Gugl and Zodrow (2014) for the derivation.
} 
perceive that increasing their capital tax unilaterally may change the amount of capital employed in the jurisdiction (even though in the symmetric equilibrium with all jurisdictions acting identically this, in fact, will not occur). Substituting from the results of differentiating the government budget constraint and the firm's first order condition, the perceived change in the jurisdiction's capital in response to an increase in the capital tax is

$$
\frac{d K}{d}=\frac{1 \quad F_{K B} K}{F_{K K}+F_{K B}} .
$$

Gugl and Zodrow (2014) prove that the denominator of $d K / d \tau$ is unambiguously negative, which follows from the assumptions of a constant returns to scale production function and government budget balance. The numerator reflects the difference between the increase in the marginal cost of capital, which equals 1 and the benefit of the associated marginal increase in $B$ on the marginal productivity of capital, given by $F_{K B} K$. If, from the firm's perspective, the marginal cost of using the capital tax to finance the purchase of more business public services (modeled as additional purchases of the numeraire good) is greater (less) than the marginal benefit so that $1>F_{K B} K\left(1<F_{K B} K\right)$, firms will lower (increase) their demand for capital and $d K / d t$ will be negative (positive).

The first order condition for the optimal capital tax is

$$
K\left(\begin{array}{ll}
F_{B} & 1
\end{array}\right)+F_{B} \frac{d K}{d}=0
$$

Consistent with Bayinder-Upmann (1998), Gugl and Zodrow show that (3) implies that the sign of $d K / d t$ uniquely determines the efficiency properties of the capital tax equilibrium, as the business public service is provided efficiently $\left(F_{B}=1\right)$ if the perceived change in the capital stock $d K / d t=0$, under-provided $\left(F_{B}>1\right)$ if $d K / d t<0$, and over-provided $\left(F_{B}<1\right)$ if 


\section{$d K / d t>0$.}

These outcomes in turn depend on the log (sub/super) modularity properties of the production function. There is neither perceived inflow nor outflow of capital if $1 F_{K B} K=0$ or, using Young's Theorem $\left(F_{K B}=F_{B K}\right)$, if ${ }_{B K}=F_{B K}\left(K / F_{B}\right)=F_{K B}\left(K / F_{B}\right)=1 / F_{B}$. That is, the numerator of $d K / d \tau$ is zero if and only if the elasticity of the marginal productivity of the public service with respect to capital is equal to the inverse of the marginal productivity of the public service. It is thus impossible to have efficient provision in the case of a production function that is $\log$ submodular and strictly concave in $(K, B)$. To see this, note that if the production function is log submodular, ${ }_{B K}<F_{K}(K / F)$, and if it is $\log$ modular, ${ }_{B K}=F_{K}(K / F) .{ }^{10}$ Efficiency requires $F_{B}=1$ and thus ${ }_{B K}=1$. But given that $F_{K}(K / F)<1$ by our assumption of strict concavity of the production function in $K$, the numerator of $d K / d \tau$ can never equal zero. Thus production functions that are $\log$ submodular in $(K, B)$ cannot result in an equilibrium with efficient provision of the business public service. Indeed, the case of a production function that is $\log$ submodular always results in underprovision under the capital tax. To see this, note that overprovision results only if $F_{B}<1$, which occurs only if the numerator of $d K / d \tau$ is negative; this requires ${ }_{B K}>1$, which, by log submodularity, is impossible since $F_{K}(K / F)<1 .{ }^{11}$ On the other hand, if the production function is $\log$ supermodular, $F_{B}=1$ and ${ }_{B K}=1$ can hold simultaneously, so that efficient provision, underprovision, and overprovision are all possible.

The results of this section are summarized in Table 1 . The general pattern observed is that as the production function moves from log submodularity to log supermodularity, the likelihood

\footnotetext{
10 See the Appendix for the derivation of this expression of $\log$ (sub)modularity.

11 See Gugl and Zodrow (2014) for an alternative proof of this result.
} 
of underprovision of public services declines. The intuition underlying this result is the following. Recall that if the production function is log submodular, the marginal productivity of capital relative to output decreases as more public service is provided, while the opposite occurs if the production function is log supermodular. In the former case, the benefits of tax-financed increases in government public services (the capital productivity effect) decrease with the level of public services and are not large enough to offset the cost of tax-induced outflows of capital (the base erosion effect), so that underprovision results. By comparison, overprovision is more likely to occur in the case of a log supermodular production function, as the benefits of taxfinanced increases in government public services increase with the level of public services.

Recall that in the case of the production tax, efficient provision occurs precisely when the production function moves from log submodularity to $\log$ supermodularity, that is, when it is $\log$ modular. By comparison, with the capital tax, underprovision still occurs when the production function is log modular. This result occurs because the production tax is assessed on a less mobile base (effectively both immobile labor and mobile capital) than is the capital tax. As a result, the base erosion effect that arises under the capital tax when the production function is $\log$ modular is larger than under the production tax, and underprovision prevails. The capital tax can thus result in efficient provision only when the production tax is characterized by overprovision (the capital productivity effect outweighs the base erosion effect), that is, when the production function is log supermodular and the capital productivity effect just offsets the base erosion effect under the capital tax so that business public services are provided efficiently.

Finally, note that Gugl and Zodrow (2014) also prove that for production functions that are log modular and log submodular in $(K, B)$, the production tax is unambiguously more efficient than the capital tax. By comparison, the relative efficiency properties of the two taxes are theoretically ambiguous if the production function is log supermodular. 


\section{[Table 1 goes here]}

\section{SIMULATION RESULTS}

In this section, we provide some simulation results that illustrate the results outlined above and provide an indication of the relative magnitudes of the various effects analyzed, including the extent of underprovision or overprovision of business public services and the associated efficiency costs. We consider various scenarios of financing business public services with both a production tax and capital tax.

\section{A. Log Modular Production Functions}

The first set of results, presented in Table 2, considers the most common log modular production function, the Cobb-Douglas production function. All of our simulations assume the capital-labor ratio is equal to 0.25 , which is generally consistent with the empirical literature. ${ }^{12}$ In the first and second columns we consider various combinations of the capital share parameter and the public services share parameter $\quad .{ }^{13}$ We report the efficient production tax rate $(t)$ for each set of parameter values in the third column (recall that a production tax is efficient in the $\log$ modular Cobb-Douglas case); in fact, the efficient production tax is equal to the output elasticity of public services (and thus also to ${ }_{K B}$ ), which equals the public services share parameter, i.e., $t=$ (columns 2-3). We report the optimal capital tax rate as a percentage of the gross return to capital $r+$ in the fourth column. The range of potential capital tax rates is quite large, $11 \% \quad[/(r+)] \quad 45 \%$. However, this is not surprising, as the range of business

\footnotetext{
12 For example, Spaliara (2009) finds a capital-labor ratio (measured as the ratio of the value of the capital stock to the number of employees) for large UK firms in 2004 of roughly 0.23 , and capital intensity has been increasing in recent years (Elsby, Hobijn, and Sahin, 2013).

13 We include some relatively large values of the public services share parameter to examine their implications for the simulations; note also that the public services shares under the capital tax, which are more comparable to the observed shares, are roughly 10-45 percent smaller than those under the efficient production tax. Estimates of the capital share usually fall in the range of 0.25-0.40 (Elsby, Hobijn, and Sahin, 2013).
} 
public services provided is large as well. Moreover, because the taxation of capital income varies considerably across states, a fairly wide range of potential taxes on capital income is plausible.

State and local taxes on capital income include three primary components. ${ }^{14}$ The first is the state corporate income tax, with statutory state tax rates that vary from 0-10 percent, and effective tax rates that depend on the details of the tax, including the level of debt finance and the nature of formula apportionment for multi-state firms. The second is the local property tax, with property tax rates that range from about $0.2-2.0$ percent of property value which, when expressed relative to capital income, might reflect additional capital taxes of $1-20$ percent. The third is the extent to which sales taxes paid on business inputs are not shifted forward as higher consumer prices.

Combined state and local sales tax rates vary from 0-10 percent ${ }^{15}$ and Ring (1999) estimates that about 40 percent of the base of the typical state sales tax consists of business purchases. This additional tax burden, expressed as a percentage of income, could be large or small, depending on how much of the sales tax burden is shifted forward to consumers. Thus, the extent of the taxation of capital income varies considerably across states. Finally, we report the degree of underprovision of business public services with capital taxation in the fifth column, and the reduction in income due to the use of the inefficient capital tax in the sixth column.

Several patterns can be observed in Table 2. As the public services share parameter declines, the marginal productivity of public services relative to the marginal productivity of capital at any given level of capital declines as well; this implies that business public services financed with the capital tax are relatively less desirable, so the optimal tax rate on capital

\footnotetext{
14 Note that our model could also be interpreted in the context of international tax competition, in which case the relevant taxes would reflect the national taxes applied to capital income and a national value-added tax.

15 Tax Foundation, 2015, "State and Local Sales Tax Rates in 2014," http://taxfoundation.org/article/state-andlocal-sales-tax-rates-2014.
} 
income also declines. Holding the public services share parameter fixed, a relatively low capital share requires a relatively high capital tax rate to raise the required revenue. Note that in each case the efficient production tax rate is lower than the comparable capital tax rate, which is as expected given the broader base of the production tax. Most importantly, the use of the capital tax results in significant underprovision of public services (by 11-52 percent), coupled with reductions in the income of local residents (between 0.04-4.07 percent). As would be expected, the magnitude of the inefficiency under the capital tax regime increases with increases in the values of the public services share parameter as more public services must be purchased to produce efficiently, and declines with increases in the capital share parameter as more revenue is raised with a given tax rate.

\section{[Table 2 goes here]}

\section{B. Log Submodular Production Functions}

The Cobb-Douglas production function, which has an elasticity of substitution between each pair of inputs of one, is commonly used in the literature. However, the assumption of a unitary elasticity of substitution between labor and capital is controversial; for example, Chirinko (2002) argues that most empirical studies find an elasticity of substitution in production between labor and capital that lies between 0.2 and 0.6, and Chirinko, Fazzari, and Meyer (2004) obtain a central estimate of $\quad=0.4$.

On the other hand, empirical evidence on the elasticity of substitution between capital and public services is limited. In a recent survey of the effects of public investment on private capital, Pereira and Andraz (2013) note that most studies simply assume a Cobb-Douglas production function, implying a unitary elasticity of substitution. By comparison, although they do not directly measure the elasticity of substitution between capital and public services, Munnell (1990) and Eisner (1991) provide evidence which suggests that public and private 
capital are highly substitutable. Moreover, a moderately high elasticity of substitution seems plausible for many business public services provided by state and local governments. For example, private capital could relatively easily substitute for water supply infrastructure, public transportation, police protection (surveillance and other security systems and more secure structures), and fire protection (sprinkler and monitoring systems, and more fire retardant construction materials).

Accordingly, we consider next the case of a constant elasticity of substitution (CES) production function that allows for substitution elasticities other than one. The function is given by $F(K, B, L)=\left[\begin{array}{ll}K+B+(1 \quad L\end{array}\right]^{1 /}$, where is the elasticity of substitution in production and $=\left(\begin{array}{l}1\end{array}\right) /$, with ${ }_{B K}=(1 \quad)(K / F)$ and ${ }_{K}=(K / F)$. As noted above, the CES function is log supermodular with ${ }_{B K}>{ }_{K}$ if and only if $<1$, and $\log$ submodular with ${ }_{B K}<{ }_{K}$ if and only if $>1$.

We simulate the model for various parameter values. To obtain an interior solution for $B$ while still allowing for the possibility of an efficient solution, we consider only $0<\gamma<1$. $^{16} \mathrm{We}$ also choose parameter values such that the optimal capital tax rates fall into a plausible range; note, however, that many parameter combinations would result in unreasonably high capital tax rates in the model.

Consider first the case of a log submodular CES production function with an elasticity of substitution between capital and business public services greater than one $(>1)$. The results shown in Table 3.A confirm that, as discussed in the previous section, both the production and

\footnotetext{
16 Given our parameter values the capital share for the CES production function ranges from 22 percent to 68 percent. The shares are very similar under both tax regimes and the efficient equilibrium with user charges.
} 
capital taxes result in underprovision of business public services (columns 3 and 6). We also show the resulting reductions in residents' income for each tax, relative to an efficient equilibrium with user charges (columns 4 and 7).

These results confirm that the production tax is always less inefficient than the capital tax for a CES production function with an elasticity of substitution greater than one. Moreover, the underprovision of public services associated with the production tax is minimal, ranging from 0.04-0.41 percent. By comparison, with the capital tax the degree of underprovision is as high as nearly 12 percent. Column 2 of Table 3.A shows how the optimal capital tax rates change as the elasticity of substitution in production increases. Higher substitutability implies less public services and therefore lower capital tax rates, so it is less costly for the local jurisdictions to provide a level close to the efficient level; thus, the extent of underprovision declines as the substitution elasticity increases.

The efficiency losses reported for both taxes in Table 3.A are quite small. These occur because of the relatively low marginal productivity of the public service compared to capital and labor and the relatively high elasticity of substitution in production. In our parameter specifications, both capital and labor have a much higher coefficient than public services. As a result, the efficient amount of public services is relatively small in comparison to the amount of labor and capital employed and it is relatively easy to substitute labor and capital for public services, so that even if public services were eliminated entirely the output level would not decline significantly. A small difference in public services between the actual amount and the efficient amount will thus have only modest effects on output. Output is highly correlated with residents' income, which is our measure of welfare. Thus efficiency losses are even smaller in percentage terms, relative to the percentage decrease in public services.

[Table 3.A goes here] 
Figures 1 and 2 illustrate the results from Table 3.A graphically, confirming that capital tax rates always exceed production tax rates, and that both the production and capital taxes result in underprovision of business public services. Figure 2 shows the percentage deviation between the efficient level of public service and the level of public service provided under the two taxes as a function of the substitution elasticity. Until the results are virtually indistinguishable, an increase in the production substitution elasticity results in a smaller percentage deviation from the efficient level. As mentioned above, the intuition is that with higher substitutability the optimal public service level falls and it is less costly for the local jurisdictions to provide a level close to the efficient amount. In all cases, consistent with our analytical results, the production tax outperforms the capital tax.

[Figures 1 and 2 go here]

Table 3.B again considers the case of a log submodular CES production function with an elasticity of substitution between capital and business public services greater than one $(>1)$, but in this case assumes that the coefficient for capital is smaller than in Table 3.A $(=0.35)$ and the coefficient for public services is larger $(=0.10)$. The general patterns are identical, but with more public services and less capital, both capital income and production tax rates are higher and the degree of under-provision is larger, although still very small (less than 1 percent in all of the simulations) in the case of the production tax while ranging from roughly 9 to 25 percent for the capital tax. For the reasons described above, the efficiency losses under both taxes are relatively small, although they do reach 0.34 percent of income under the capital tax.

\section{[Table 3.B goes here]}

In untabulated results, we also calculated capital income, labor income, and profits under each parameter constellation. The clear pattern was that capital income was higher and labor income lower under the production tax than under the capital tax. Profits under both tax regimes 
are quite similar and steadily decline as the substitution elasticity increases.

\section{Log Supermodular Production Functions}

Consider next the case of a log supermodular CES production function with an elasticity of substitution between capital and public services less than one $(<1)$. In this case, the production tax always leads to overprovision of business public services, while the capital tax results in underprovision for values of close to one, and then efficient provision and eventually overprovision as the substitution elasticity declines. These results are confirmed in Table 4.A, where under the capital tax efficient provision occurs when $=0.53,{ }^{17}$ with larger (smaller) values of resulting in under- (over-) provision of business public services.

These results indicate that for sufficiently large values of the substitution elasticity ( 0.7 ), the production tax results in a smaller deviation from the optimal supply of business public services and is clearly more efficient than the capital tax. However, as the substitution elasticity declines further, the two taxes are roughly comparable in their efficiency properties. This reflects the fact that the production tax results in ever-increasing overprovision as the substitution elasticity moves away from $=1$, while the capital tax approaches the efficient level of provision at a value of $=0.53$, roughly half the value that corresponds to efficiency under the production tax. Indeed, when $=0.30$, both taxes are quite high (a capital tax rate of 70 percent and a production tax rage of 48 percent) and result in overprovision of roughly $27-28$ percent, and an income loss of roughly 4-5 percent.

\section{[Table 4.A goes here]}

Figures 3 and 4 illustrate the results from Table 4.A graphically. These figures confirm that capital tax rates again always exceed production tax rates, and an increase in the substitution

\footnotetext{
17 Given the other parameters, this occurs for the value of that satisfies $=\left[\begin{array}{ll}K+(1 & )\end{array}\right] /\left[\begin{array}{ll}(1 & )\end{array}\right]$. 
elasticity leads to less underprovision in the case of the production tax with the efficient level at a substitution elasticity of 1 . Consistent with our analytical results, the capital tax can lead to overprovision, efficient provision and underprovision. While the capital tax is more efficient for substitution elasticities close to 0.53 , the production tax outperforms the capital tax for a large range of elasticities.

\section{[Figures 3 and 4 go here]}

Table 4.B considers the case of a log supermodular CES production function with an elasticity of substitution in production smaller than one $(<1)$, but in this case assumes that the coefficient for capital is smaller than in Table 4.A with $(=0.35)$ and the coefficient for public services $(=0.10)$. The general patterns in Tables 4.A and 4.B are identical and the numerical results are broadly similar, but with a higher marginal rate of substiution between public services and capital than in Table 3.A, both the capital income and production tax rates are higher. In this case, the efficient level of provision of business public services under the capital tax occurs when the elasticity of substitution in production is $=0.46$.

As in the case of log submodular production functions, we also calculated capital income, labor income, and profits under each parameter constellation. The same pattern was evident, as capital income was higher and labor income lower under the production tax than under the capital tax, and profits under both tax regimes were quite similar, declining steadily as the substitution elasticity increased.

To summarize, this section illustrates the theoretical results presented in Section II using some numerical examples. Since the performance of production taxes and capital taxes cannot be ranked in the case of log supermodular production functions, we calculate numerically the optimal production and capital taxes for a range of parameter constellations. In most, but not all cases, we find that the production tax is more efficient than the capital tax, consistent with the 
conjectures discussed in the introduction, and that in these cases the difference in efficiency between the two taxes can be relatively large (Figure 2 and Figure 4 for roughly $>0.5$ ). By comparison, when the production function is log supermodular $(<1)$ and the elasticity of substitution in production is relatively small (roughly 0.5 or less), the capital tax can be more efficient than the production tax; however, in these cases the differences between the more efficient capital tax and the less efficient production tax tend to be small (Figure 4).

\section{RELATIONSHIP OF CAPITAL TAX RESULTS TO THE EARLIER LITERATURE}

In this section, we briefly relate the results presented above to some others that have appeared in the literature. As noted in the introduction, ZM obtain two main results in their analysis of the effects of capital taxation on the provision of business public services. First, starting from an initial equilibrium in which the efficient level of business public services is financed solely with head taxes, they find that — as in the case of public services provided to households - the use of the property tax to finance local business public services leads to underprovision of such services, as local governments reduce reliance on the property tax to avoid driving mobile capital out of their jurisdictions. Second, once property tax finance of business public services is introduced (through an exogenous reduction in the permitted level of head taxes from the efficient level), the effect of a property tax increase on the level of business public services is theoretically ambiguous; specifically, it depends on how the perceived responsiveness of mobile capital, which interacts with the initial tax rate when it is positive in the initial equilibrium, varies as the tax rate increases.

ZM made two assumptions to ensure that an increase in the tax rate on capital in a jurisdiction always leads to an outflow of capital. First, ZM (equation 17) made a stability assumption that, as Dhillon et al. (2007, p. 407) describe, "rules out a destabilizing 'virtuous circle' in which more capital facilitates more public good provision which enhances productivity 
to the extent that the demand for capital increases, and so on." We follow Dhillon et al. and ZM in adopting this stability assumption; indeed Dhillon et al. show that this assumption is essential for the existence of a capital tax equilibrium. Moreover, assuming only two inputs, mobile capital and the public input, they show that the stability condition is violated for the CobbDouglas production function with CRS and more generally for CES production functions. By comparison, we show that this stability condition is satisfied by our three-factor production function, as long as it is strictly concave in both capital and the public service.

Adoption of this stability assumption, however, does not guarantee that a capital tax rate increase leads to capital outflow from the jurisdiction. To ensure this condition, ZM (p. 363, equation 16) also assume that “...the marginal cost of diverting a unit of output to public services for firms (which is equal to unity) is greater than the associated increase in output due to the increased marginal productivity of capital." The two assumptions together guarantee that the local government anticipates an outflow of capital if it unilaterally increases the tax rate on capital. Noiset 1995, Sinn 1997, Matsumoto 1998, and Dhillon et al. 2007 all question this latter assumption, and instead do not rule out the case in which the capital tax results in more public services which raise the productivity of capital sufficiently to make jurisdictions believe that by raising taxes they can attract more capital. For example, Dhillon et al. replace ZM's condition with a weaker condition and show that a capital tax equilibrium exists and that it may involve underprovision, efficient provision, or overprovision of public services. Complementing their analysis, Gugl and Zodrow (2014) focus on the global properties of production functions and show that the assumptions of (1) strict concavity of the production function in capital and public services, and (2) strict concavity in the marginal product of capital (public service) in public service (capital) are sufficient to establish that underprovision of public services financed by capital taxes must occur at an interior solution, and that production functions that are $\log$ 
modular or log submodular in capital and the public service satisfy the latter assumption. If the production function is log supermodular, however, the second assumption is not satisfied, and all three cases — over, efficient, and underprovision — are possible.

Dhillon et al. (2007) also show that the Cobb-Douglas production function with decreasing returns to scale (DRS) always results in underprovision of public services in a capital tax equilibrium. This result is consistent with our analysis, as the Cobb-Douglas technology with DRS is an example of a log modular technology. Our analysis is also complementary to Dhillon et al. in that we show that the introduction of a fixed factor in our model implies that the assumption of constant returns to scale in production is consistent with the existence of a capital tax equilibrium.

Taking a different approach, Matsumoto (1998) treats business public services as a pure public input in a model that assumes constant returns to scale in all inputs and a fixed number of firms. As in the case of publicly provided private goods analyzed by Gugl and Zodrow (2014), Matsumoto finds that the effect of capital taxes on the supply of capital to the taxing jurisdiction is theoretically ambiguous. Matsumoto assumes an initial capital tax equilibrium, and thus does not focus on the stability condition mentioned above and existence of the equilibrium. He finds that whether there is under-provision, efficient provision, or over-provision of business public services in a capital tax equilibrium depends on the sign of the difference between the marginal productivity of the public service and the increased marginal productivity of capital due to the increased business public services financed with an increase in the capital tax. Our analysis extends these results by showing that the assumption that the production function is log modular or log submodular in capital and public service is sufficient to rule out efficient or overprovision of public services in his analysis.

We close this section by describing a recent contribution to the literature by Matsumoto 
and Sugahara (2014), who consider several forms of taxation and focus on production functions of the form $F[(B) K,(B) L]$ where the technology is CRS in private factors only so that $F=F_{L} L+F_{K} K .{ }^{18} 19$ They find that a uniform tax on labor and capital is efficient if the substitution elasticity between labor and capital is one or if the public service enters the production function in Hicks neutral form. Our results differ because we assume a different production function — one that is CRS in all inputs for the reasons noted above — that is, thus generally not of the form $F[(B) K,(B) L] .^{20}$

\section{CONCLUSION}

The results of the simulations of our admittedly highly stylized model of interjurisdictional tax competition suggest that under many (although certainly not all) circumstances it is more efficient to finance business public services with an origin-based production tax rather than a source-based capital tax; these results are broadly consistent with the arguments by Bird (2002) and McLure (2003) discussed in the introduction. Note that this result is not an implication of the famous production efficiency theorem of Diamond and Mirrlees (1971) — which proves that factor taxes should not be used (under certain circumstances) — since, in the case analyzed in this paper, the tax revenues from the capital tax analyzed are used to finance a public services that increases the marginal productivity of capital. Instead, the key

\footnotetext{
18 Two other recent papers are related to our analysis but less directly relevant. Carbonnier (2013) constructs a tax competition model characterized by underprovision of business public services and examines whether decentralization of infrastructure decisions is more efficient than a centralized approach, given the inefficiency associated with subnational interjurisdictional tax competition. Pauser (2013) constructs a ZM-type model that includes an imperfect labor market with unemployment that exists because labor is paid more than its marginal product, and shows that overprovision of business public services can arise under these circumstances.

19 Another strand of this literature considers the effects of tax competition in models that include both public provision of business inputs and "Leviathan" local governments that are assumed to benefit directly from the size of the budgets they control; for example, see Edwards and Keen (1996) and Wilson (2005). In such models, tax competition is more likely to be efficiency enhancing, as it limits the extent to which the budget-maximizing tendencies of local governments result in over-expansion of the public sector.

${ }^{20}$ Of the production functions considered in our simulations, only the Cobb-Douglas production function is of the form $F[(B) K, \quad(B) L]$.
} 
issue is whether a production tax or a capital tax more closely approximates the user charge for business public services that would ensure economic efficiency. This in turn depends on which tax most closely balances the benefits of tax-financed increases in government public services in the form of an increase in the marginal productivity of capital (the capital productivity effect) against the cost of tax-induced outflows of capital (the base erosion effect). For log submodular production functions (e.g., CES with $>1$ ) and log modular production functions (e.g, CD), this balance is always struck best by the production tax. For log supermodular production functions (e.g., CES with <1), the results are ambiguous, but the production tax is superior in some cases (e.g., a CES production function with in the upper portion of the range $0<1$ ), and in those cases in which it is not (e.g., a CES production function with in the lower portion of the range $0<1$, the efficiency losses from using the production tax, relative to those that occur under the capital tax, are relatively small. Intuitively, in contrast to the more broad-based production tax, the capital tax focuses its distortions on the capital market, so that for any given level of revenue and provision of business public services, the base erosion effect tends to be relatively large. For example, for the CES production function (Figures 2 and 4), this occurs for all relatively large values of the elasticity of substitution in production, including all values greater than one. However, for a sufficiently small production substitution elasticity, the capital usage distortion attributable to the use of the capital tax and thus the magnitude of the base erosion effect are relatively low, and the efficiency properties of the capital income and production taxes are broadly similar.

We close with some speculative comments on the relevance of these results for subnational tax policy. In the United States, the tax most closely approximating a consumptionbased, origin-based VAT was the Single Business Tax (SBT) in Michigan, which was a 
significant source of revenue for the state until it was phased out, ending in $2007 .{ }^{21}$ Although Hines (2002) argues that the SBT was an attractive tax alternative for the state, he notes that problems in dealing with multi-state firms and especially strong opposition to significant taxation of firms with no profits - even though entirely consistent with the principles of benefit taxation - ultimately doomed the tax. (Of course, property taxation of businesses also suffers from the latter problem.)

More generally, the use of production-based business taxes at the state and local level in the United States is generally declining. Indeed, many states that use a formula-apportioned state corporate income tax have moved away from taxing the production-based components of the tax by switching to formulas that put a relatively small or zero weight on the productive factors used by businesses within the taxing jurisdiction (payroll and property); they instead have attached larger (sometimes unitary) weights on a destination-based measure of gross sales. These reductions in production-based business taxes may reflect the effects of interjurisdictional tax competition — perhaps coupled with a realization that business taxes were significantly higher than the value of public services received by business (Testa and Mattoon, 2006), often because property taxes on businesses are assessed at rates similar to those applied to residential property. ${ }^{22}$ Under these circumstances, the imposition of an additional production-based tax would be inconsistent with the "benefit-related" taxation of business envisioned by Bird (2000).

On the other hand, taxation of businesses — even in excess of benefits received — may

\footnotetext{
21 In addition, the state of New Hampshire utilizes an income-based, origin-based VAT known as the Business Enterprise Tax; see Kenyon (1996) for a discussion.

22 Note, however, that property taxation of businesses can be viewed as analogous to benefit taxation to the extent that zoning or negotiation between local governments and businesses ensures that property taxes paid equal the sum of benefits received and the costs of externalities imposed by local businesses (Fischel, Oates and Youngman, 2011). The extent to which this occurs in practice is unclear (Zodrow, 2001, 2014). Even in this case, however, the imposition of an additional production-based tax would result in business taxes paid that would exceed benefits received.
} 
be politically popular. For example, recent experience in Canada suggests that the replacement of provincial retail sales taxes (RSTs) which tax business purchases to a significant extent with a pure consumption tax linked to the national Goods and Services Tax (GST) — known as Harmonized Sales Tax (HST) - faces fierce political opposition. ${ }^{23}$ For example, FightHST, a political organization advocating repeal of the HST in British Columbia, stated in a voters guide to a mail-in referendum that, "Exempting business from sales taxes means government is taking all of its sales tax revenues from consumers inside our economy and then transferring \$1.9 billion of it back to corporations, some of which are headquartered in Europe, Asia or the U.S." (Elections Canada, 2011, p.5).

In order to appease voters before the referendum, the provincial government announced modifications to the HST that included a rate reduction from 12 percent to 10 percent by 2014 , an increase of the corporate income tax rate from 10 percent to 12 percent in 2012 , and the postponement of a planned small business tax reduction that had been scheduled for April 2012 (CBC News, 2011). These actions can be interpreted as an attempt to convince voters that business in British Columbia is paying "its fair share." Nevertheless, despite these efforts, in August 2011 a majority of the voters who cast their mail-in ballot voted to repeal the HST, and the government of British Columbia is now looking for other ways to restructure its tax system to meet the challenge of increasing health and education expenditures. As harmonization with the federal GST is no longer an option, a provincial origin-based VAT might be considered as a replacement for the RST. It would, after all, deal with some of the criticism levied against the HST by taxing local production rather than local consumption, and in addition might be more efficient than the provincial retail sales tax it would replace.

\footnotetext{
23 Both retail sales taxes and value-added taxes in principle tax consumption goods while exempting purchases of business inputs. However, in practice, exemption of business purchases is much more easily achieved under the value-added tax than under the typical retail sales tax (see, for example, Gillis, Mieszkowski, and Zodrow (1996)).
} 


\section{ACKNOWLEDGMENTS}

We thank Brad Hackinen for excellent research assistance, including programming all of the simulations and generating the figures. We have benefited from the comments of two anonymous referees, Tim Goodspeed, Jay Wilson, Jim Hines, Marco Gonzalez Navarro, Matt Krzepkowski, Steve Bullion, and the participants of a conference on "Subnational Government Competition," sponsored by The Office of Tax Policy Research at the University of Michigan, the Center for Business and Economic Research at the University of Tennessee, and the Department of Economics at the University of Georgia and held on April 25-26, 2014 at the University of Tennessee, Knoxville, TN.

\section{DISCLOSURES}

The authors have no financial arrangements that might give rise to a conflict of interest with respect to the research reported in this paper.

\section{REFERENCES}

Bayindir-Upmann, Thorsten, 1998. "Two Games of Interjurisdictional Competition When Local Governments Provide Industrial Public Goods.” International Tax and Public Finance 5 (4), 471-487.

Bird, Richard M., 2000. "Subnational VATS: Experience and Prospects." In Proceedings of the Ninety-Third Annual Conference on Taxation of the National Tax Association, 223-228. National Tax Association, Washington, DC.

Bucovetsky, Sam, and John D. Wilson, 1991. "Tax Competition with Two Tax Instruments." Regional Science and Urban Economics 21 (3), 333-350.

Carbonnier, Clément, 2013. Decentralization and Tax Competition between Asymmetrical Local Governments: Theoretical and Empirical Evidence.” Public Finance Review 41 (4), 391-420.

CBC News, 2011. "B.C. Promises HST Cut to $10 \%$ by 2014: Tax Hike for Corporations and Cheques for Families also Promised." CBC News, May 25, http://www.cbc.ca/news/canada/british-columbia/story/2011/05/25/bc-hst-changes.html.

Chirinko, Robert S., 2002. "Corporate Taxation, Capital Formation, and the Substitution Elasticity between Labor and Capital.” National Tax Journal 55 (2), 339-355. 
Chirinko, Robert S., Steven M. Fazzari, and Andrew P. Meyer, 2004. "That Elusive Elasticity: A Long Run Panel Approach to Estimating the Capital-Labor Substitution Elasticity." CES-ifo Working Paper 1240. CES-ifo, Munich, Germany.

Devereux, Michael P., and Simon Loretz, 2013. "What Do We Know about Corporate Tax Competition? National Tax Journal 66 (3), 745-774.

Dhillon, Amrita, Myrna Wooders, and Ben Zissimos, 2007. "Tax Competition Reconsidered." Journal of Public Economic Theory 9 (3), 391-423.

Diamond, Peter A., and James A. Mirrlees, 1971. "Optimal Taxation and Public Production I: Production Efficiency.” American Economic Review 61 (1), 8-27.

Edwards, Jeremy, and Michael Keen, 1996. "Tax Competition and Leviathan.” European Economic Review 40 (1), 113-134.

Elections Canada, 2011. HST Referendum Voters Guide. Gatineau, Quebec. http://www.abbotsfordtoday.ca/wp-content/uploads/2011/06/HST_Voters_Guide.pdf.

Eisner, Robert, 1991. "Infrastructure and Regional Economic Performance: Comment.” New England Economic Review (Sept.), 47-58.

Feehan, James P., and Mutsumi Matsumoto, 2000. "Productivity-enhancing Public Investment and Benefit Taxation: The Case of Factor-Augmenting Public Inputs." Canadian Journal of Economics 33 (1), 114-121.

Fischel, William A., Wallace E. Oates, and Joan Youngman, 2011. “Are Local Property Taxes Regressive, Progressive, or What?” Unpublished manuscript. University of Maryland, College Park, MD.

Gillis, Malcolm, Peter Mieszkowski, and George R. Zodrow, 1996. "Indirect Consumption Taxes: Common Issues and Differences among the Alternative Approaches." Tax Law Review 51 (Summer), 725-724.

Gordon, Roger H., 1986. "Taxation of Investment and Savings in the World Economy." American Economic Review 76 (5), 1086-1102.

Gramlich, Edward M., 1993. "Infrastructure Investment: A Review Essay.” Journal of Economic Literature 32 (3), 1176-1196.

Gugl, Elisabeth, and George R. Zodrow, 2014. "Tax Competition and the Efficiency of 'BenefitRelated' Business Taxes." RISE (Rice Initiative for the Study of Economics) Working Paper No. 14-013. Rice University, Houston, TX, http://economics.rice.edu/rise/working-papers/taxcompetition-and-efficiency-benefit-related-business-taxes.

Hamilton, Bruce W., 1983. "The Flypaper Effect and Other Anomalies.” Journal of Public Economics 22 (3), 347-361. 
Hines, James R. Jr., 2002. “Michigan's Flirtation with the Single Business Tax.” Working paper. Office of Tax Policy Research, University of Michigan, Ann Arbor, MI.

Kanbur, Ravi, and Michael Keen, 1993. "Jeux Sans Frontieres: Tax Competition and Tax Coordination when Countries Differ in Size.” American Economic Review 83 (4), 877-892.

Keen, Michael, and Maurice Marchand, 1997. "Fiscal Competition and the Pattern of Public Spending.” Journal of Public Economics 66 (1), 33-53.

Kenyon, Daphne, 1996. “A New State VAT: Lessons from New Hampshire.” National Tax Journal 49 (3), 381-399.

Matsumoto, Mutsumi, 1998. A Note on Tax Competition and Public Input Provision." Regional Science and Urban Economics 28 (4), 465-473.

Matsumoto, Mutsumi, 2000a. "A Note on the Composition of Public Expenditure under Capital Tax Competition.” International Tax and Public Finance 7 (6), 691-697.

Matsumoto, Mutsumi, 2000b. "A Tax Competition Analysis of Congestible Public Inputs." Journal of Urban Economics 48 (2), 242-259.

Matsumoto, Mutsumi, and James P. Feehan, 2010. "Capital-tax Financing and Scale Economies in Public-input Production.” Regional Science and Urban Economics 40 (2-3), 116-121.

Matsumoto, Mutsumi, and Kota Sugahara, 2014. "Factor Taxation and Public-Input Provision Under Tax Competition: A Note.” Discussion Paper Series No. 2014-01. Kyoto Sangyo University, Kyoto, Japan.

McLure, Charles E., Jr., 2003. "The Value Added Tax on Electronic Commerce in the European Union." International Tax and Public Finance 10 (6), 753-762.

Munnell, Alicia H., 1991. "How Does Public Infrastructure Affect Regional Economic Performance.” New England Economic Review (Sept.), 69-104.

Noiset, Luc, 1995. "Pigou, Tibout, Property Taxation, and the Underprovision of Local Public Goods: A Comment.” Journal of Urban Economics 38 (23), 312-316.

Oates, Wallace E., and Robert M. Schwab, 1988. "Economic Competition Among Jurisdictions: Efficiency Enhancing or Distortion Inducing?” Journal of Public Economics 35 (3), 333-354.

Oates, Wallace E., and Robert M. Schwab, 1991. "The Allocative and Distributive Implications of Local Fiscal Competition.” In Kenyon, Daphne A., and John Kincaid (eds.), Competition among States and Local Governments: Efficiency and Equity in American Federalism, 127-140. The Urban Institute Press, Washington, DC. 
Pereira, Alfredo M., and Jorge M. Andraz, 2013. "On the Economic Effects of Public Infrastructure Investment: A Survey of the International Evidence.” Working Paper No. 108. Department of Economics, College of William and Mary, Williamsburg, VA.

Peters, Michael, and Aloysius Siow, 2002. "Competing Premarital Investments.” Journal of Political Economy 110 (3), 592-608.

Phillips, Andrew, Robert Cline, Caroline Sallee, Michelle Klassen, and Daniel Sufranski, 2013. "Total State and Local Business Taxes: State by State Estimates for Fiscal Year 2013." Ernst and Young and Council on State Taxation, Washington DC, http://www.cost.org/WorkArea/DownloadAsset.aspx?id=87982.

Razin, Assaf, and Efraim Sadka, 1991. "International Tax Competition and Gains from Tax Harmonization." Economics Letters 37 (1), 69-76.

Richter, Wolfram F., 1994. "The Efficient Allocation of Local Public Factors in Tiebout's Tradition." Regional Science and Urban Economics 24 (3), 323-340.

Sinn, Hans-Werner, 1997. "The Selection Principle and Market Failure in Systems Competition." Journal of Public Economics 66 (2), 247-274.

Sinn, Hans-Werner, 2003. The New System Competition. Wiley-Blackwell, Hoboken, NJ.

Smith, Lones, 2006. "The Marriage Model with Search Frictions.” Journal of Political Economy 114 (6), 1124-1144.

Spaliara, Marina-Eliza, 2009. "Do Financial Factors Affect The Capital-Labour Ratio?: Evidence from UK Firm-Level Data." Working Paper 09-04. Centre for Finance and Credit Markets School of Economics, Nottingham, UK.

Testa, William A., and Richard Mattoon, 2006. "Is There a Role for Gross Receipts Taxation?" National Tax Journal 60 (4), 821-840.

Tiebout, Charles, 1956. A Pure Theory of Local Expenditures. Journal of Political Economy 64 (5), 416-424.

Wildasin, David E., 1988. "Nash Equilibria in Models of Fiscal Competition.” Journal of Public Economics 35 (2), 229-240.

Wilson, John D., 1986. “A Theory of Interregional Tax Competition.” Journal of Urban Economics 19 (3), 296-315.

Wilson, John D., 1999. “Theories of Tax Competition.” National Tax Journal 52 (2), 269-304.

Wilson, John D., 2005. "Welfare-Improving Competition for Mobile Capital.” Journal of Urban Economics 57 (1), 1-18.

Wilson, John D., and David E. Wildasin, 2004. “Tax Competition: Bane or Boon?” Journal of 
Public Economics 88 (6), 1065-1091.

Zodrow, George R., 2001. "The Property Tax as a Capital Tax: A Room with Three Views." National Tax Journal 54 (1), 139-156.

Zodrow, George R., 2003. "Reflections on the Economic Theory of Local Tax Incentives." State Tax Notes 28 (10), 891-900.

Zodrow, George R., 2014. "Intrajurisdictional Capitalization and the Incidence of the Property Tax." Regional Science and Urban Economics 45 (March), 57-66.

Zodrow, George R. and Peter Mieszkowski, 1983. "The Incidence of the Property Tax. The Benefit View vs. the New View.” In Zodrow, George R. (ed.), Local Provision of Public Services: The Tiebout Model after Twenty-Five Years, 109-129. Academic Press, New York, NY.

Zodrow, George R. and Peter Mieszkowski, 1986. "Pigou, Tiebout, Property Taxation and the Underprovision of Local Public Goods." Journal of Urban Economics 19 (3), 356-370.

\section{APPENDIX A. LOG (SUPER/SUB) MODULARITY}

This appendix discusses the concept of modularity and explores further the relationship between $\log$ (sub/super) modularity of the production function and the relative efficiency of production and capital taxes in the model utilized in the text.

\section{A.1 Modularity of the Production Function}

Modularity means that a production process can be divided into modules, which can be executed in any particular order without changing the output of each module or the total output produced. This occurs only if the marginal productivity of one input is independent of the level of other inputs. For example, the production function $F(q, z)=q+z, \quad, \quad>0$, is modular with two modules $q$ and $z$ and cross derivatives $F_{q z}=F_{z q}=0$.

With supermodularity or submodularity, such a division of the production function into different modules is not possible. For example, with the two-factor production function $F(q, z)$, the marginal product of one of the inputs is no longer independent of the levels of the other 
input. In the case of a supermodular production function, the marginal product of one input increases with more of the other input, i.e., $F_{q z}>0, F_{z q}>0$, while in the case of submodularity, the marginal product of one input decreases with more of the other input, i.e., $F_{q z}<0, F_{z q}<0$.

The concept of modularity can also be illustrated by comparing the sums of outputs produced with different input combinations. Consider two different levels of input for each of two inputs, where a smaller subscript indicates the smaller of the two amounts. A production function is modular if the sum of the outputs generated by $\left(q_{1}, z_{1}\right)$ and $\left(q_{2}, z_{2}\right)$ is the same as the sum of outputs generated by $\left(q_{1}, z_{2}\right)$ and $\left(q_{2}, z_{1}\right)$, that is, if $F\left(q_{1}, z_{1}\right)+F\left(q_{2}, z_{2}\right)=F\left(q_{1}, z_{2}\right)+F\left(q_{2}, z_{1}\right)$. Rewriting this equation yields $F\left(q_{2}, z_{2}\right) \quad F\left(q_{2}, z_{1}\right)=F\left(q_{1}, z_{2}\right) \quad F\left(q_{1}, z_{1}\right)$. Dividing by $z_{2} \quad z_{1}$ yields

$$
\frac{F\left(q_{2}, z_{2}\right) \quad F\left(q_{2}, z_{1}\right)}{z_{2} z_{1}}=\frac{F\left(q_{1}, z_{2}\right) \quad F\left(q_{1}, z_{1}\right)}{z_{2} z_{1}}
$$

which implies that, holding the amount of $q$ constant at different levels, the increases in output due to an increase of $z_{2} \quad z_{1}$ in input $z$ are the same at both levels of $q$. As the change in input $z$ approaches zero, this implies $F\left(q_{2}, z\right) / \quad z=F\left(q_{1}, z\right) / \quad z$ or $\quad F\left(q_{2}, z\right) / \quad z \quad F\left(q_{1}, z\right) / z=0$. Dividing both sides by $q_{2} \quad q_{1}$ and taking the limit as $q_{2} \quad q_{1}$ approaches zero implies (A.2) $\frac{{ }^{2} F(q, z)}{z q}=F_{z q}=0$.

Thus, with modularity the marginal productivity of $z$ does not depend on the level of $q$. Similarly, the marginal productivity of $q$ is independent of the level of $z\left(F_{q z}=0\right)$.

With supermodularity, the marginal productivity of $z$ is greater at a higher level of $q$ so that $F_{z q}>0$; similarly, $F_{q z}>0$. By comparison, with submodularity, the presence of a higher level of $q$ lowers the marginal productivity of $z$ so that $F_{z q}<0$; similarly, $F_{q z}<0$. 
Analogous expressions determine log super/submodularity, except the changes in output are measured in percentage terms. For example, for log modularity, the sum of the logs of the outputs at different levels of inputs must be the same. That is,

$\log F\left(q_{1}, z_{1}\right)+\log F\left(q_{2}, z_{2}\right)=\log F\left(q_{1}, z_{2}\right)+\log F\left(q_{2}, z_{1}\right)$. Using percentage changes, derivations analogous to those above yield

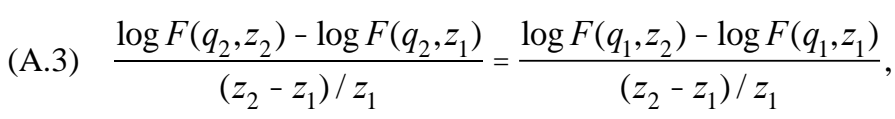

which implies that the percentage increases in output due to a given percentage increase in the input $z$ are the same at different levels of $q$. Thus log modularity requires

(A.4) $\frac{\log F\left(q_{2}, z\right)}{\log z} \quad \frac{\log F\left(q_{1}, z\right)}{\log z}=0$,

which in turn implies

(A.5) $\frac{{ }^{2} \log F(q, z)}{\log z \log q}=0$

while log supermodularity implies

(A.6) $\frac{{ }^{2} \log F(q, z)}{\log z \log q}>0$

and log submodularity implies

(A.7) $\frac{{ }^{2} \log F(q, z)}{\log z \log q}<0$.

Log super/sub modularity of the production function can also be related to the output elasticities of the production function with respect to its inputs. Define the output elasticity of input $z$ as ${ }_{z}=F_{z}(q, z) z / F(q, z)$, so that Error! Reference source not found. can be written (A.8) $\quad z_{z}\left(q_{2}, z\right) \quad{ }_{z}\left(q_{1}, z\right)=0$. 
Taking the limit of this expression as $q_{2} \quad q_{1}$ approaches zero yields

$$
{ }_{z} / q=\left(F_{z q} z F \quad F_{q} F_{z} z\right) / F^{2}
$$

The sign of this expression depends on the sign of the numerator, or

(A.10) $\operatorname{sign}\left({ }_{z} / q\right)=\operatorname{sign}\left(F_{z q} z / F_{q} \quad F_{z} z / F\right)=\operatorname{sign}\left(F_{q z} z / F_{q} \quad F_{z} z / F\right)$.

Define ${ }_{q z}=F_{q z} z / F_{q}$ as the elasticity of the marginal product $F_{q}$ with respect to $z$. Thus, a production function is: (1) $\log$ submodular if ${ }_{q z}{ }_{z}<0$ or ${ }_{q z} /{ }_{z}<1$; (2) log modular if ${ }_{q z} \quad{ }_{z}=0$ or ${ }_{q z} /{ }_{z}=1$; and (3) log supermodular if ${ }_{q z} \quad{ }_{z}>0$ or ${ }_{q z} /{ }_{z}>1$. Defining ${ }_{z q}$ and $q_{q}$ analogously, symmetry implies that a production function is: (1) log submodular if ${ }_{z q} \quad<0$ or ${ }_{z q} /{ }_{q}<1$; (2) log modular if ${ }_{z q} \quad{ }_{q}=0$ or ${ }_{z q} /{ }_{q}=1$; and (3) $\log$ supermodular if ${ }_{z q} \quad{ }_{q}>0$ or ${ }_{z q}{ }^{\prime}{ }_{q}>1$.

\section{A.2 Modularity and the Efficiency of Production and Capital Taxes}

The intuition underlying the log modularity properties of the production function and the relative efficiency properties of production and capital taxes in the model can be described as follows. As described in the text, for both taxes an efficient equilibrium occurs when a change in the tax rate has no effect on the perceived capital stock, as the "base erosion" effect (the tendency for a tax increase that increases the cost of capital to drive out capital) is exactly offset by the "capital productivity" effect (the increase in capital productivity due to a tax-financed increase in business public services). If one orders possible production functions in terms of the magnitude of their $\quad q_{z} \quad$, then as one moves from log submodularity to log modularity to $\log$ supermodularity, the marginal productivity of capital is higher as the level of the business public 
service increases, so it is more likely that the capital productivity effect will dominate the base erosion effect.

In the case of the production tax, the capital productivity effect is smaller than (equal to, larger than) the base erosion effect as the production function is log submodular (log modular, $\log$ supermodular), and the result is under-provision (efficient provision, over-provision) of business public services. In the case of the capital tax, the base erosion effect of the tax is larger at any given tax rate and level of revenue, since all of the tax applies directly to capital (rather than to both capital and labor as under the production tax). Thus, it is more likely that the base erosion effect will dominate the capital productivity effect, and this is indeed the case for log submodular and log modular production functions, and for some log supermodular production functions. However, if the increase in marginal productivity of capital is sufficiently greater at larger levels of $B$, the capital productivity effect becomes large enough that overprovision of business public services results.

To elaborate on the results in the case of the capital tax, note that the numerator of $d K / d$ in (14) is $\left(1 F_{K B} K\right)$. If $B$ is set at the efficient level - that is, it satisfies $F_{B}=1-$ at a given level of $K$, then (using Young's Theorem) ${ }_{B K}=F_{K B} K$. With log submodularity or log modularity, ${ }_{B K} \quad{ }_{K} \quad$ 0. Strict concavity of the production function with respect to $K$ implies ${ }_{K}<1$, so that ${ }_{B K}=F_{K B} K<1$, the base erosion effect as perceived by the local jurisdiction is always larger than the capital productivity effect, and underprovision of business public services always results. However, with log supermodularity, ${ }_{B K} \quad{ }_{K}>0$, so it is possible - although not guaranteed - that at $F_{B}=1,{ }_{B K}=F_{K B} K>1$ (since ${ }_{B K}$ is no longer bound by ${ }_{K}$ ), and overprovision of business public services may result. 
Table 1

Summary of Results

\begin{tabular}{|c|c|c|c|}
\hline \hline Production Function & $\begin{array}{c}\text { Public Service } \\
\text { Provision with a } \\
\text { Production Tax }\end{array}$ & $\begin{array}{c}\text { Public Service } \\
\text { Provision with a } \\
\text { Capital Tax }\end{array}$ & More Efficient Tax \\
\hline \hline Log submodular & Underprovision & Underprovision & Production Tax \\
\hline Log modular & Efficient provision & Underprovision & Production Tax \\
\hline Log supermodular & Overprovision & $?$ & $?$ \\
\hline \hline
\end{tabular}




\section{Table 2}

Optimal Production and Capital Tax Rates, Underprovision of Public Services and Associated Income Losses, for a Cobb-Douglas Production Function and Various Parameter Values

\begin{tabular}{|c|c|c|c|c|c|}
\hline $\begin{array}{c}(1) \\
\text { Capital } \\
\text { Share } \\
\text { Parameter } \\
(\quad)\end{array}$ & $\begin{array}{c}(2) \\
\text { Public } \\
\text { Services } \\
\text { Share } \\
\text { Parameter } \\
(\quad)\end{array}$ & $\begin{array}{c}(3) \\
\text { Production } \\
\text { Tax Rate } \\
(t) \\
(\%)\end{array}$ & $\begin{array}{c}(4) \\
\text { Capital Tax } \\
\text { Rate } \\
(/(r+)) \\
(\%)\end{array}$ & $\begin{array}{c}\text { (5) } \\
\text { Underprovision } \\
\text { of Public } \\
\text { Services (\%) } \\
\text { with Capital } \\
\text { Tax }\end{array}$ & $\begin{array}{c}(6) \\
\text { Decrease in } \\
\text { Income }(\%) \\
\text { with Capital } \\
\text { Tax }\end{array}$ \\
\hline 0.40 & 0.20 & 20 & 33.33 & 39.76 & 2.11 \\
\hline 0.40 & 0.15 & 15 & 27.27 & 31.25 & 0.91 \\
\hline 0.40 & 0.10 & 10 & 20.00 & 22.00 & 0.28 \\
\hline 0.40 & 0.05 & 5 & 11.11 & 11.66 & 0.04 \\
\hline 0.35 & 0.20 & 20 & 36.36 & 43.16 & 2.57 \\
\hline 0.35 & 0.15 & 15 & 30.00 & 34.27 & 1.13 \\
\hline 0.35 & 0.10 & 10 & 22.22 & 24.36 & 0.35 \\
\hline 0.35 & 0.05 & 5 & 12.50 & 13.11 & 0.05 \\
\hline 0.25 & 0.20 & 20 & 44.44 & 52.04 & 4.07 \\
\hline 0.25 & 0.15 & 15 & 37.50 & 42.50 & 1.87 \\
\hline 0.25 & 0.10 & 10 & 28.57 & 31.20 & 0.61 \\
\hline 0.25 & 0.05 & 5 & 16.67 & 17.46 & 0.09 \\
\hline
\end{tabular}

Note: Because these simulations assume a Cobb-Douglas production function, business public services are underprovided with a capital tax and provided efficiently with a production tax. 
Table 3.A

Optimal Production and Capital Tax Rates, Underprovision of Business Public Services and Income Losses, for a CES Production Function (Log Submodular with $>1$ )

$$
(=0.40,=0.05)
$$

\begin{tabular}{|c|c|c|c|c|c|c|}
\hline Parameters & & Capital Tax & & & oduction Tax & \\
\hline $\begin{array}{c}(1) \\
\text { Elasticity of } \\
\text { Substitution in } \\
\text { Production } \\
(>1)\end{array}$ & $\begin{array}{c}(2) \\
\text { Capital } \\
\text { Tax Rate } \\
\left(\begin{array}{c}/(r+)) \\
(\%)\end{array}\right.\end{array}$ & $\begin{array}{c}(3) \\
\text { Inefficient } \\
\text { Provision } \\
\text { of Public } \\
\text { Services } \\
(\%)\end{array}$ & $\begin{array}{c}(4) \\
\text { Decrease } \\
\text { in } \\
\text { Income } \\
(\%)\end{array}$ & $\begin{array}{c}(5) \\
\text { Production } \\
\text { Tax Rate } \\
(t) \\
(\%)\end{array}$ & $\begin{array}{c}(6) \\
\text { Inefficient } \\
\text { Provision } \\
\text { of Public } \\
\text { Services } \\
(\%)\end{array}$ & $\begin{array}{c}(7) \\
\text { Decrease } \\
\text { in } \\
\text { Income } \\
(\%)\end{array}$ \\
\hline 1.01 & 10.85 & -11.67 & -0.04 & 4.85 & -0.04 & 0.00 \\
\hline 1.05 & 9.86 & -11.64 & -0.03 & 4.30 & -0.15 & 0.00 \\
\hline 1.10 & 8.75 & -11.51 & -0.02 & 3.70 & -0.26 & 0.00 \\
\hline 1.20 & 6.88 & -11.01 & -0.01 & 2.74 & -0.37 & 0.00 \\
\hline 1.30 & 5.40 & -10.28 & -0.01 & 2.03 & -0.41 & 0.00 \\
\hline 1.40 & 4.23 & -9.42 & -0.01 & 1.50 & -0.41 & 0.00 \\
\hline 1.50 & 3.30 & -8.50 & 0.00 & 1.11 & -0.38 & 0.00 \\
\hline 1.60 & 2.56 & -7.55 & 0.00 & 0.83 & -0.34 & 0.00 \\
\hline 1.70 & 1.98 & -6.63 & 0.00 & 0.61 & -0.30 & 0.00 \\
\hline 1.80 & 1.53 & -5.76 & 0.00 & 0.45 & -0.26 & 0.00 \\
\hline 1.90 & 1.17 & -4.95 & 0.00 & 0.34 & -0.22 & 0.00 \\
\hline 2.00 & 0.90 & -4.22 & 0.00 & 0.25 & -0.18 & 0.00 \\
\hline 2.50 & 0.23 & -1.69 & 0.00 & 0.06 & -0.07 & 0.00 \\
\hline
\end{tabular}




\section{Table 3.B}

Optimal Production and Capital Tax Rates, Underprovision of Business Public Services and Income Losses, for a CES Production Function (Log Submodular with $>1$ )

$$
(=0.35,=0.10)
$$

\begin{tabular}{|c|c|c|c|c|c|c|}
\hline Parameters & & Capital Tax & & & duction Tax & \\
\hline $\begin{array}{l}(1) \\
\text { Elasticity of } \\
\text { Substitution in } \\
\text { Production } \\
(>1)\end{array}$ & $\begin{array}{c}(2) \\
\text { Capital } \\
\text { Tax Rate } \\
\left(\begin{array}{c}/(r+)) \\
(\%)\end{array}\right.\end{array}$ & $\begin{array}{c}(3) \\
\text { Inefficient } \\
\text { Provision } \\
\text { of Public } \\
\text { Services } \\
\quad \%)\end{array}$ & $\begin{array}{c}(4) \\
\text { Decrease } \\
\text { in } \\
\text { Income } \\
(\%)\end{array}$ & $\begin{array}{c}(5) \\
\text { Production } \\
\text { Tax Rate } \\
(t) \\
(\%)\end{array}$ & $\begin{array}{c}(6) \\
\text { Inefficient } \\
\text { Provision } \\
\text { of Public } \\
\text { Services } \\
(\%)\end{array}$ & $\begin{array}{c}(7) \\
\text { Decrease } \\
\text { in } \\
\text { Income } \\
(\%)\end{array}$ \\
\hline 1.01 & 21.79 & -24.48 & -0.34 & 9.76 & -0.11 & 0.00 \\
\hline 1.05 & 20.21 & -24.70 & -0.31 & 8.89 & -0.33 & 0.00 \\
\hline 1.10 & 18.42 & -24.84 & -0.26 & 7.91 & -0.47 & 0.00 \\
\hline 1.20 & 15.35 & -24.63 & -0.19 & 6.27 & -0.74 & 0.00 \\
\hline 1.30 & 12.80 & -24.13 & -0.13 & 4.97 & -0.89 & 0.00 \\
\hline 1.40 & 10.67 & -23.37 & -0.09 & 3.95 & -0.93 & 0.00 \\
\hline 1.50 & 8.91 & -22.34 & -0.06 & 3.13 & -0.93 & 0.00 \\
\hline 1.60 & 7.42 & -21.18 & -0.04 & 2.49 & -0.90 & 0.00 \\
\hline 1.70 & 6.18 & -19.92 & -0.03 & 1.98 & -0.84 & 0.00 \\
\hline 1.80 & 5.14 & -18.57 & -0.02 & 1.57 & -0.78 & 0.00 \\
\hline 1.90 & 4.26 & -17.19 & -0.01 & 1.25 & -0.70 & 0.00 \\
\hline 2.00 & 3.53 & -15.80 & -0.01 & 0.99 & -0.63 & 0.00 \\
\hline 2.50 & 1.33 & -9.40 & 0.00 & 0.32 & -0.33 & 0.00 \\
\hline
\end{tabular}


Table 4.A

Optimal Production and Capital Tax Rates, Underprovision of Business Public Services and Income Losses, for a CES Production Function (Log Supermodular with <1)

$$
(=0.40,=0.05)
$$

\begin{tabular}{|c|c|c|c|c|c|c|}
\hline \multirow{2}{*}{$\begin{array}{c}\text { Parameters } \\
(1) \\
\text { Elasticity of } \\
\text { Substitution in } \\
\text { Production } \\
\quad(>1)\end{array}$} & \multicolumn{3}{|c|}{ Capital Tax } & \multicolumn{3}{|c|}{ Production Tax } \\
\hline & $\begin{array}{c}(2) \\
\text { Capital } \\
\text { Tax Rate } \\
\left(\begin{array}{c}/(r+)) \\
(\%)\end{array}\right.\end{array}$ & $\begin{array}{c}(3) \\
\text { Inefficient } \\
\text { Provision } \\
\text { of Public } \\
\text { Services } \\
(\%)\end{array}$ & $\begin{array}{c}(4) \\
\text { Decrease } \\
\text { in } \\
\text { Income } \\
(\%)\end{array}$ & $\begin{array}{c}(5) \\
\text { Production } \\
\text { Tax Rate } \\
(t) \\
(\%)\end{array}$ & $\begin{array}{c}(6) \\
\text { Inefficient } \\
\text { Provision } \\
\text { of Public } \\
\text { Services } \\
(\%)\end{array}$ & $\begin{array}{c}(7) \\
\text { Decrease } \\
\text { in } \\
\text { Income } \\
(\%)\end{array}$ \\
\hline 0.30 & 69.96 & 27.36 & -4.24 & 48.01 & 28.40 & -4.53 \\
\hline 0.40 & 53.31 & 18.11 & -1.08 & 33.50 & 15.63 & -0.82 \\
\hline 0.50 & 39.79 & 5.08 & -0.06 & 24.23 & 10.77 & -0.24 \\
\hline 0.60 & 30.05 & -2.92 & -0.01 & 17.38 & 5.85 & -0.05 \\
\hline 0.70 & 23.09 & -7.54 & -0.05 & 12.60 & 2.99 & -0.01 \\
\hline 0.80 & 17.98 & -10.05 & -0.06 & 9.22 & 1.39 & 0.00 \\
\hline 0.90 & 14.11 & -11.27 & -0.05 & 6.78 & 0.49 & 0.00 \\
\hline 0.95 & 12.52 & -11.55 & -0.04 & 5.82 & 0.21 & 0.00 \\
\hline 0.99 & 11.38 & -11.65 & -0.04 & 5.15 & 0.04 & 0.00 \\
\hline
\end{tabular}




\section{Table 4.B}

Optimal Production and Capital Tax Rates, Underprovision of Business Public Services and Income Losses, for a CES Production Function (Log Supermodular with $<1$ )

$$
(=0.35,=0.10)
$$

\begin{tabular}{|c|c|c|c|c|c|c|}
\hline \multirow{2}{*}{$\begin{array}{c}\text { Parameters } \\
(1) \\
\text { Elasticity of } \\
\text { Substitution in } \\
\text { Production } \\
(>1)\end{array}$} & \multicolumn{3}{|c|}{ Capital Tax } & \multicolumn{3}{|c|}{ Production Tax } \\
\hline & $\begin{array}{c}(2) \\
\text { Capital } \\
\text { Tax Rate } \\
\left(\begin{array}{c}/(r+)) \\
(\%)\end{array}\right.\end{array}$ & $\begin{array}{c}(3) \\
\text { Inefficient } \\
\text { Provision } \\
\text { of Public } \\
\text { Services } \\
(\%)\end{array}$ & $\begin{array}{c}(4) \\
\text { Decrease } \\
\text { in } \\
\text { Income } \\
(\%)\end{array}$ & $\begin{array}{c}(5) \\
\text { Production } \\
\text { Tax Rate } \\
(t) \\
(\%)\end{array}$ & $\begin{array}{c}(6) \\
\text { Inefficient } \\
\text { Provision } \\
\text { of Public } \\
\text { Services } \\
(\%)\end{array}$ & $\begin{array}{c}(7) \\
\text { Decrease } \\
\text { in } \\
\text { Income } \\
(\%)\end{array}$ \\
\hline 0.30 & 97.15 & 21.36 & -3.42 & 55.00 & 18.48 & -2.60 \\
\hline 0.40 & 79.93 & 15.57 & -1.10 & 44.00 & 17.21 & -1.33 \\
\hline 0.50 & 63.96 & -1.93 & -0.01 & 34.30 & 12.38 & -0.45 \\
\hline 0.60 & 50.85 & -11.38 & -0.29 & 26.00 & 4.69 & -0.04 \\
\hline 0.70 & 40.65 & -17.48 & -0.50 & 20.50 & 3.43 & -0.02 \\
\hline 0.80 & 32.60 & -22.06 & -0.57 & 16.10 & 1.88 & 0.00 \\
\hline 0.90 & 26.79 & -23.73 & -0.47 & 12.67 & 0.73 & 0.00 \\
\hline 0.95 & 24.43 & -23.95 & -0.40 & 11.25 & 0.30 & 0.00 \\
\hline 0.99 & 22.64 & -24.33 & -0.36 & 10.23 & 0.02 & 0.00 \\
\hline
\end{tabular}


Figure 1

Production and Capital Tax Rates (\%) for a CES Production Function $($ Log Submodular with $>1)(=0.40,=0.05)$

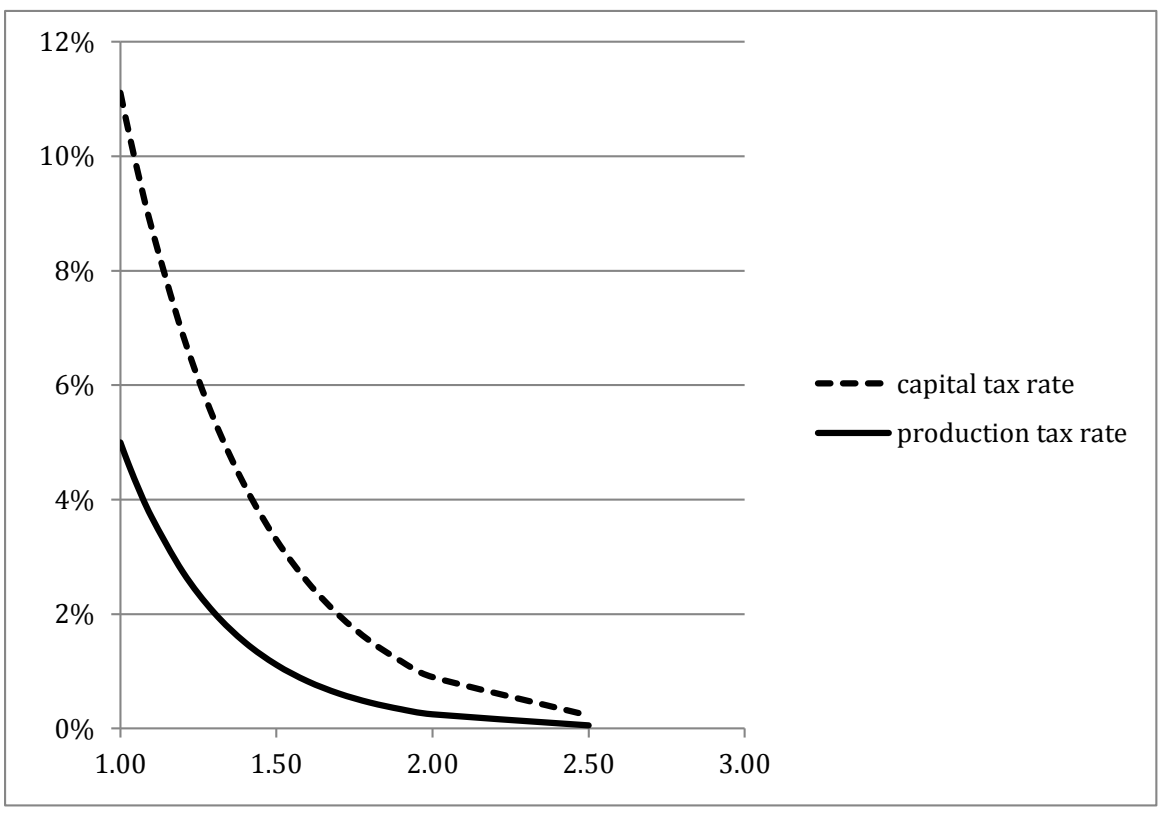


Figure 2

Deviations from Efficient Provision of Business Public Services (\%) under Production and Capital Taxes for a CES Production Function (Log Submodular with $>1)(=0.40,=0.05)$

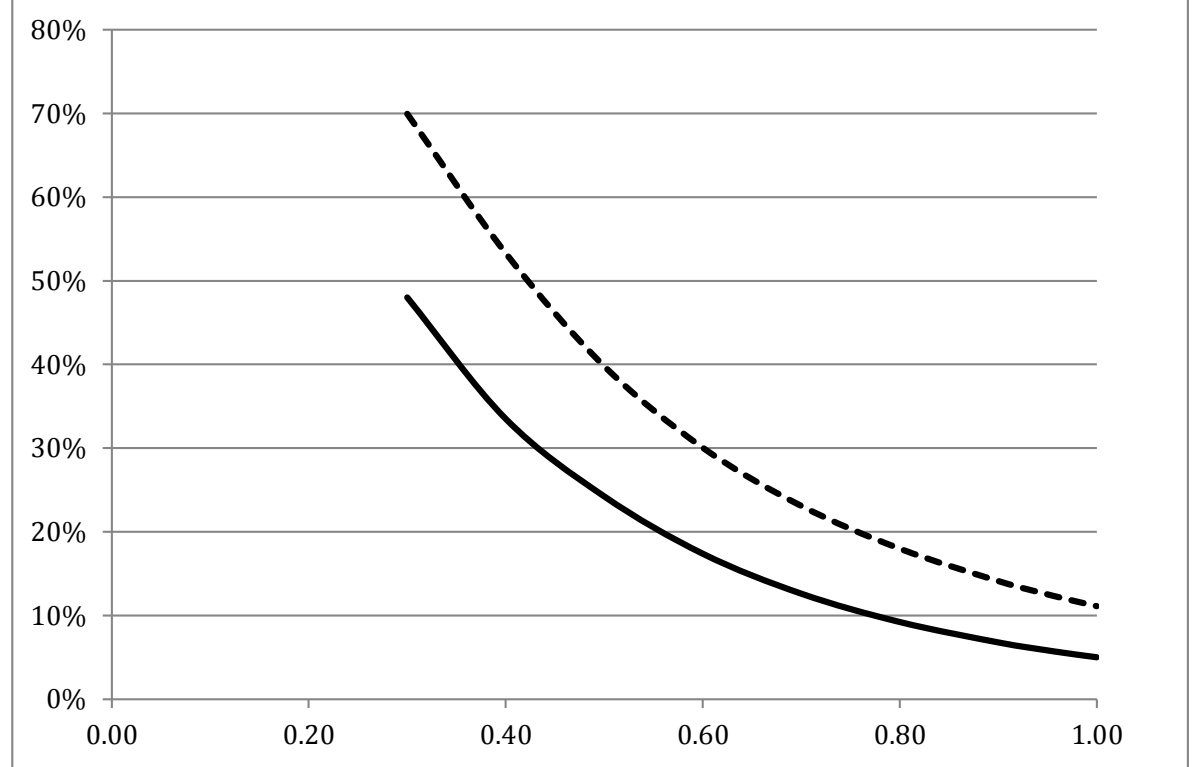




\section{Figure 3}

Production and Capital Tax Rates (\%) for a CES Production Function $($ Log Supermodular with $<1)(=0.40,=0.05)$

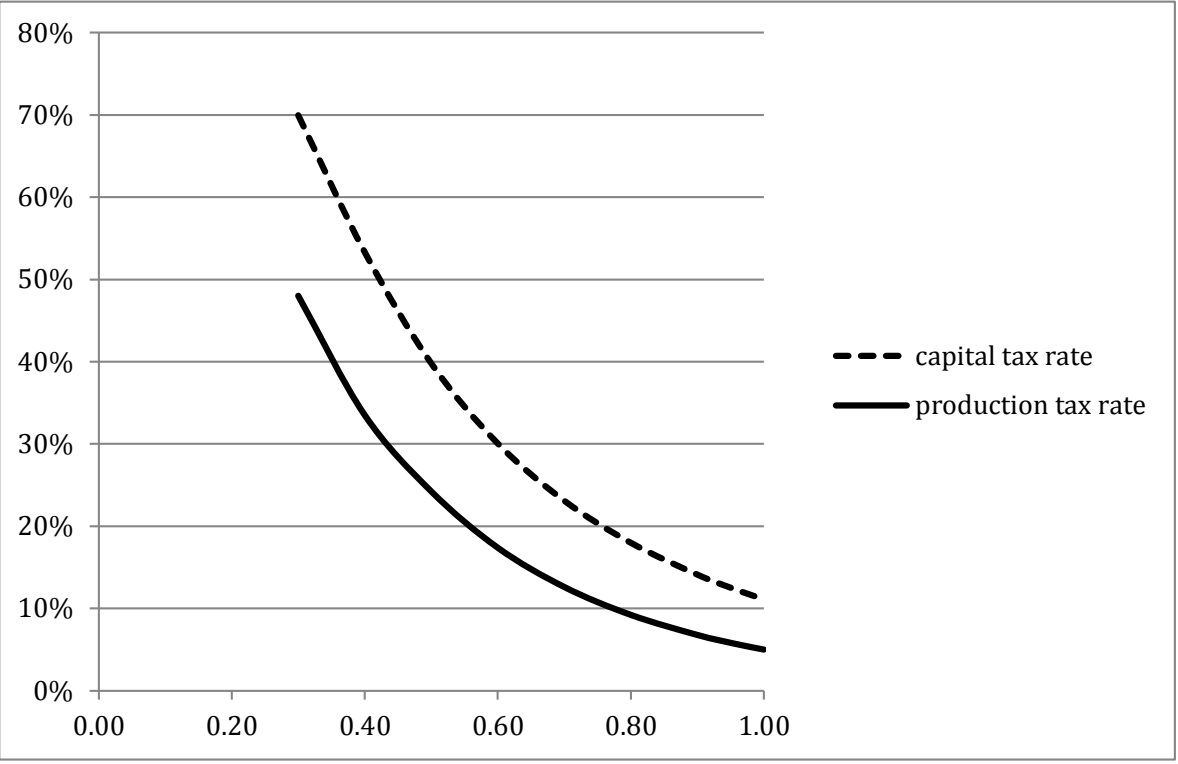




\section{Figure 4}

Deviations from Efficient Provision of Business Public Services (\%) under Production and Capital Taxes for a CES Production Function (Log Supermodular with $<1)(=0.40,=0.05)$

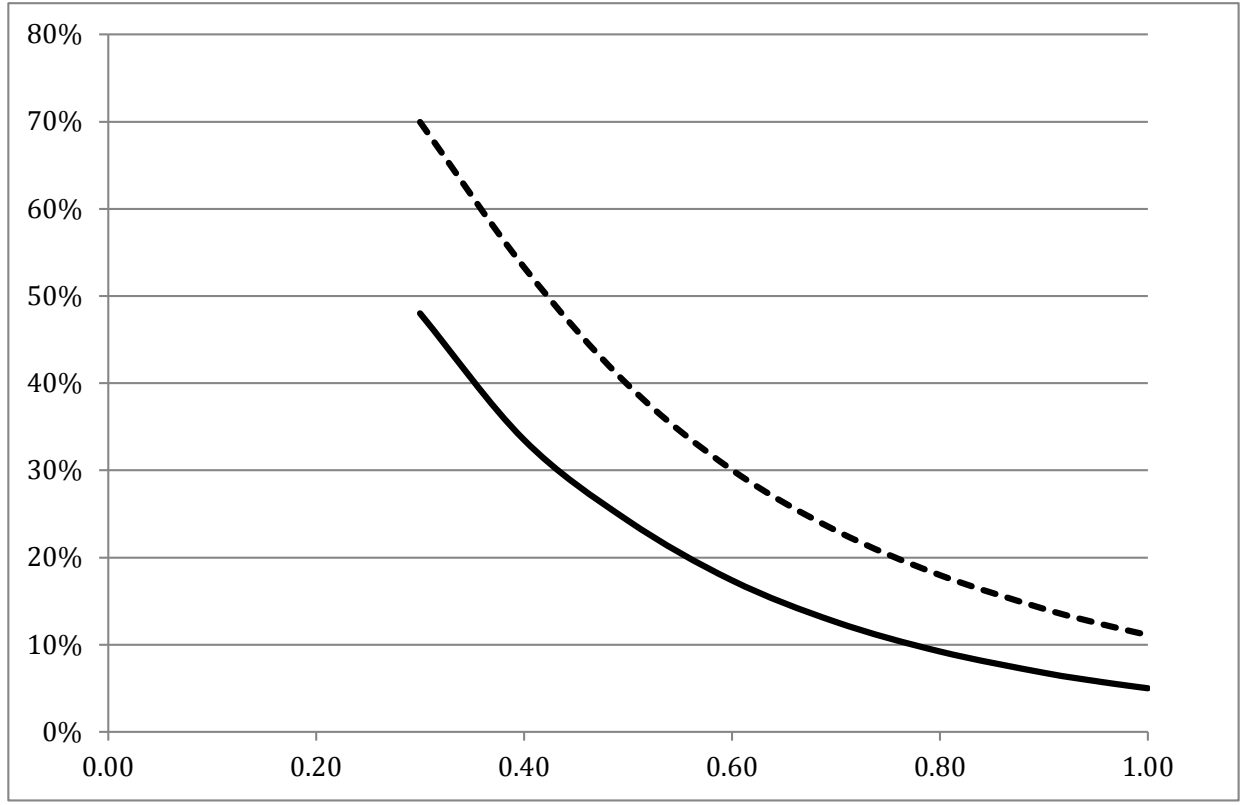

